Review

\title{
Sustainable Development of Concrete through Aggregates and Innovative Materials: A Review
}

\author{
Sergio A. Zamora-Castro ${ }^{1, *(\mathbb{C})}$, Rolando Salgado-Estrada ${ }^{1}$ (i) , Luis Carlos Sandoval-Herazo ${ }^{2}$, \\ Roberto Angel Melendez-Armenta ${ }^{2} \mathbb{D}$, Erick Manzano-Huerta ${ }^{1}$, Enriqueta Yelmi-Carrillo ${ }^{1}$ \\ and Agustín L. Herrera-May ${ }^{1,3}$ (i)
}

check for

updates

Citation: Zamora-Castro, S.A.;

Salgado-Estrada, R.;

Sandoval-Herazo, L.C.;

Melendez-Armenta, R.A.;

Manzano-Huerta, E.; Yelmi-Carrillo,

E.; Herrera-May, A.L. Sustainable

Development of Concrete through

Aggregates and Innovative Materials:

A Review. Appl. Sci. 2021, 11, 629

https://doi.org/10.3390/

app11020629

Received: 5 December 2020

Accepted: 8 January 2021

Published: 11 January 2021

Publisher's Note: MDPI stays neutral with regard to jurisdictional clai$\mathrm{ms}$ in published maps and institutional affiliations.

Copyright: $(\odot 2021$ by the authors. Licensee MDPI, Basel, Switzerland. This article is an open access article distributed under the terms and conditions of the Creative Commons Attribution (CC BY) license (https:// creativecommons.org/licenses/by/ $4.0 /)$.
1 Faculty of Engineering of the Construction and the Habitat, Universidad Veracruzana, Calzada Adolfo Ruiz Cortines 455, Fracc. Costa Verde, C.P. Boca del Río, Veracruz 94294, Mexico; rosalgado@uv.mx (R.S.-E.); emanzanohuerta@gmail.com (E.M.-H.); yelmi_91@hotmail.com (E.Y.-C.); leherrera@uv.mx (A.L.H.-M.)

2 División de Estudios de Posgrados e Investigación, Tecnológico Nacional de México/Instituto Tecnológico Superior de Misantla, Km 1.9 Carretera a Loma del Cojolite, Misantla, Veracruz 9382, Mexico; lcsandovalh@gmail.com (L.C.S.-H.); ramelendeza@misantla.tecnm.mx (R.A.M.-A.)

3 Micro and Nanotechnology Research Center, Universidad Veracruzana, Calzada Ruiz Cortines 455, Boca del Río, Veracruz 94294, Mexico

* Correspondence: szamora@uv.mx

\begin{abstract}
The use of concrete in civil infrastructure is highly demanded in structural and nonstructural elements. However, the high production of concrete could lead to severe pollution in the world. This pollution can be decreased using sustainable materials mixed with cement to obtain sustainable concrete. These sustainable materials include reinforcing fibers (e.g., steel, polypropylene, carbon fibers), recycled materials (e.g., tire rubber, crushed glass, plastic, industrial waste) as well as organic and inorganic elements as concrete aggregates and reinforcement elements. The sustainable construction materials can reduce the amount constitutive elements of concrete required for civil constructions. In addition, some sustainable materials added to cement could improve some properties of the concrete, like the compressive and flexural strength of concrete structural elements. Thus, the maintenance requirements or early replacement of these structural elements could be decreased. This review presents recent investigations about the performance of different sustainable concrete types. In addition, we include the effects on the mechanical properties of the concrete caused by the incorporation of several sustainable materials. In addition, recommendations for the use and testing of sustainable concrete are reported. These materials have potential applications in the sustainable concrete infrastructure in future smart cities.
\end{abstract}

Keywords: recycled concrete; sustainable concrete; organic fibers; inorganic fibers; industrial waste; smart cities; steel fibers

\section{Introduction}

Concrete is the material most used in the construction industry and its mechanical strength depends on the quality and properties of the aggregates, the water-cement ratio and the uniformity of the mixture [1,2]. This material is an essential component in the modern infrastructure due to its high structural resistance and durability. Concrete is widely employed in the construction of bridges, dams, tunnels and numerous physical infrastructures [3,4]. It is a key material in the recent and future infrastructure with estimation of yearly consumption of 25 billion tons [5].

The high production of cement generates environmental contamination through carbon dioxide $\left(\mathrm{CO}_{2}\right)$ emissions. For this, the use of new sustainable materials in the construction sector can contribute to decreasing the $\mathrm{CO}_{2}$ emissions and costs as well as the reuse waste materials [6]. In order to reduce greenhouse gases emissions, it is necessary to recycle waste materials and conserve the natural resources. The increment in the use of recycled materials with aggregates and cement-based materials can improve the concrete 
compatibility with the environment $[7,8]$. The partial substitution of cement for other sustainable materials may increase the durability of the concrete, reducing the maintenance of structural components [9].

The population growth and urban development demand a great amount of natural resources in the construction industry [10]. This industry has increased the cement production due the increment in the concrete consumption [11,12]. This high cement fabrication can cause close $7 \%$ of the global $\mathrm{CO}_{2}$ emissions [13]. The consumption of industrial products cause waste that may be harmful for the environment. However, several of these waste materials could be mixed with cement to obtain sustainable concrete and improve its mechanical strength and durability [14]. Thus, the sustainable concrete can be an important alternative to reuse some waste materials and reduce the problem of waste disposal $[15,16]$. Figure 1 depicts different recycled materials, organic aggregates and synthetic fibers used in sustainable concrete. The recycled materials include rubber, plastic, glass and industrial waste. The organic aggregates consider the bamboo, coconut fiber and nanocellulose. On the other hand, the synthetic and mineral fibers use steel, glass, carbon and textile fiber and epoxy resins.

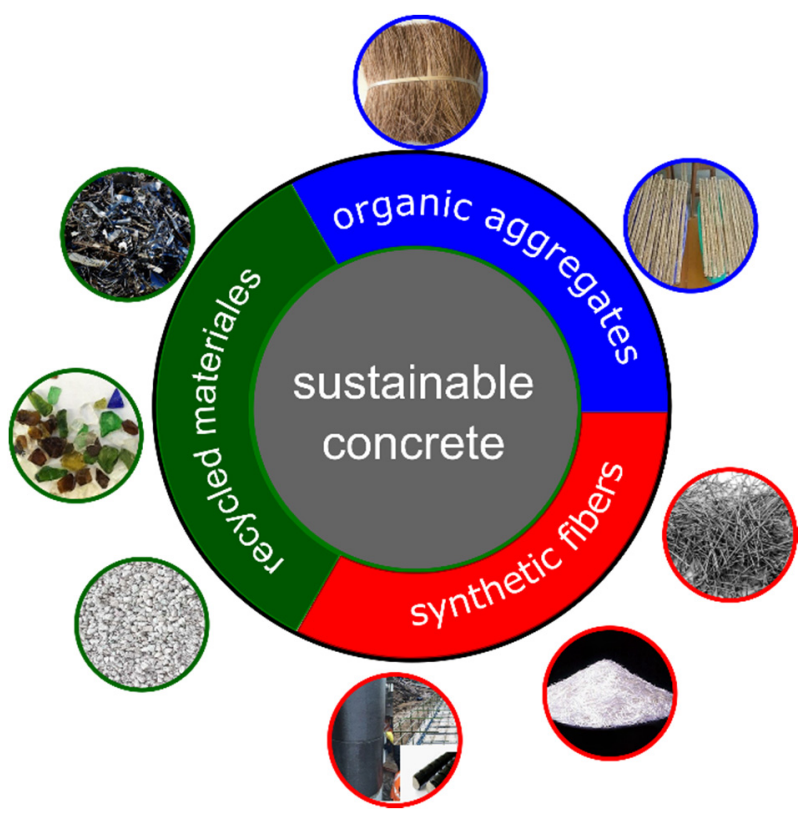

Figure 1. Diagram of different material types used in sustainable concrete.

The mechanical strength, durability and workability of concrete can be enhanced by replacing the cement or aggregates with recycled materials [17]. The incorporation of waste materials in the concrete production may contribute to the conservation of natural resources [18]. For instance, polymers added to cement may enhance the concrete strength and durability $[19,20]$. These polymers are used as matrix materials, modifiers and concrete adhesives. Bulut and Sahin [19] used polyester resin as binder in polymer concrete production [19]. This polyester resin has the following characteristics: a concentration of $60 \%$ of unsaturated polyester resin and $40 \%$ of styrene; a physical state of liquid; flash point of $34{ }^{\circ} \mathrm{C}$; ignition point (solvent) of $490^{\circ} \mathrm{C}$; specific weight of 1.13 ; viscosity of $475 \pm 75 \mathrm{cp}$; gelling time $\left(25^{\circ} \mathrm{C}\right)$ of $4 \pm 1 \mathrm{~min}$; bending strength of $100 \mathrm{MPa}$ and tensile strength of $55 \mathrm{MPa}[19]$.

In this review, we present recent investigations about different recycled materials, organic aggregates and synthetic and mineral fibers used in the concrete industry. The effects of these materials on the mechanical (compressive, tensile and flexural strength) and physical (porosity, density and water absorption) properties of concrete samples are discussed. Numerous researchers have reported methodologies for the use of these materials in sustainable concrete. Optimal dosages of these materials can enhance the 
compressive, tensile and flexural strength of the concrete. In addition, we report some suggestions for the incorporation of these materials into cement.

\section{Recycled Materials}

\subsection{Recycled Building Materials}

In recent years, a large number of buildings around the world have been demolished. It has generated close to 400 million tons of debris per year such as concrete, stone and brick, which are known as recycled aggregates [21]. The use of these recycled materials helps to reduce energy consumption and conserve natural resources. Generally, the construction sector uses aggregates obtained from the demolition of mountains that causes a high consumption of natural resources. Therefore, recycled materials represent an important alternative source in the construction industry to reduce the consumption of natural resources [22].

Richardson et al. [22] tested the freeze/thaw durability of recycled aggregate concrete and compared it with respect to concrete fabricated using virgin aggregates. Figure 2 shows a schematic view of the manufacture process for both concrete types. They reported that recycled aggregate concrete has equal durability with that of concrete with virgin aggregates. Seps et al. [23] developed tests about the freeze-and-thaw resistance and resistance to chlorides of fiber reinforced concrete, which was made from recycled concrete aggregate. They registered the lost mass and resistance after 50 freeze-thaw cycles of recycled concrete aggregate and their results indicated that recycled concrete aggregate has low resistance to freeze and thaw cycling. Gao et al. [24] investigated the compressive behavior of fiber reinforced polymer (FRP) tube confined recycled aggregate concrete (RAC). They used recycled clay brick aggregates (RCBA) that were obtained from demolished brick masonry elements. Four RAC samples were employed considering different RCBA replacement ratio of $0 \%, 50 \%, 70 \%$ and $100 \%$ at 28 days of curing. The increment in the replacement ratio of RCBA generates a low reduction in the compressive strength of the RCA samples. For ranges of replacement ratio from $0 \%$ to $50 \%$ and from $0 \%$ to $70 \%$, the compressive strength of the RCA specimens only decreased $11.8 \%$ and $12.4 \%$, respectively. Yang et al. [25] reported physical and mechanical properties of recycled concrete using high incorporation percentage of RCA and crushed clay bricks (CCB). Baena et al. [26] evaluated the effect of the incorporation of recycled coarse aggregates on the properties of hardened concrete and bond performance between concrete and FRP tubes. They employed RCA at replacement rates of $0 \%, 20 \%, 50 \%$ and $100 \%$ and reported the effect of the rebar surface configuration on the bond behavior between FRP tubes and RCA. Seara-Paz et al. [27] studied the shrinkage and creep behavior of recycled concrete using water to cement ratios of 0.50 and 0.65 and different replacement ratio of recycled aggregates $(0 \%, 20 \%, 50 \%$ and $100 \%)$. The shrinkage and creep strains increased with higher replacement ratio. Guo et al. [28] presented a study to enhance the rubber concrete behavior using two surface treatment methods ( $\mathrm{NaOH}$ and silane coupling agent) and three coating methods. The $\mathrm{NaOH}$-solution treatment improves the rubber concrete strength with respect to normal rubber concrete coating methods. In addition, the rubber concrete registered lower permeability and better durability. This rubber concrete could increase building energy efficiency and decrease noise due to its low thermal conductivity and sound transmission attenuation.

Every day, several concrete structures reach the end of their service life. Examples of these are highways and buildings among others. Thus, the process to obtain the recycled aggregates could be relatively easy. If the concrete is not recycled and it ends up in landfills, then can increase the consumption of natural resources. Therefore, recycled concrete is an important option to conserve the environmental recourses and reduce the costs in the construction industry. 


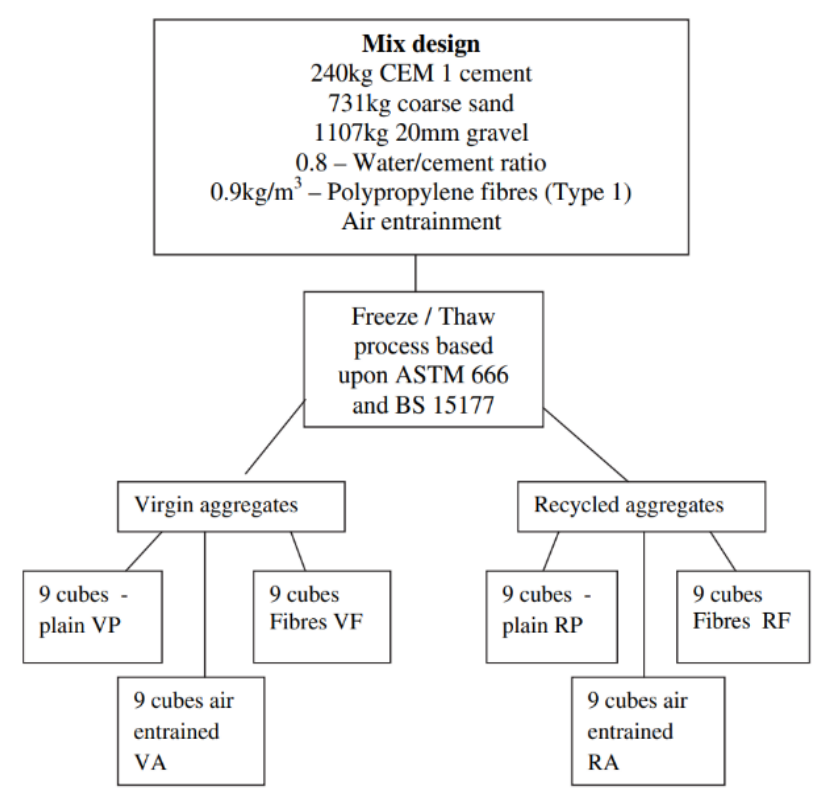

Figure 2. Schematic view of the fabrication process used in the recycled aggregate concrete and the concrete with virgin aggregates. Reprinted with permission from [22]. Copyright@ 2011, Elsevier B.V.

\subsection{Recycled Tire Rubber}

A tire is a composite of complex elastomer formulations, reinforced with plies of fibers and steel fiber [29]. The number of tires being discarded is an environmental problem in all the world. Every year nearly 1 billion tons of waste tires are discarded and only a small amount is recycled [30]. Recycled tires have been extensively studied since the end of previous century to use in asphalt pavement, waterproofing systems, membrane coating, among others [31].

Although rubber has excellent properties (e.g., high strength, great elasticity and durability), it may affect several properties of concrete. For instance, cement mixed with coarse or fine aggregate of waste tire rubber may generate concrete with lower specific density and lower compressive and tensile strength as well as higher toughness and ductility and more efficient sound insulation [32]. The variations of the physical and mechanical properties of this concrete type may depend on replacement ratio and the size of the tire particles added to concrete. Asutkar et al. [32] measured several physical and mechanical properties of rubber concrete using different percentage of replacement of rubber aggregates. The aggregates were obtained by shredding the vehicles scrap tire rubber, achieving a size range between 10 and $20 \mathrm{~mm}$. They determined that the optimum percentage of replacement of rubber aggregates can be up to $15 \%$. Even in these conditions rubber waste decreases the concrete compressive strength. Therefore, they recommend the use of rubber waste aggregates in concrete for construction components such as partition walls, road barriers, pavements, sidewalks and some other secondary elements that do not require high compressive strength of concrete. Tables 1-3 depict the mix proportion, physical properties of materials and results of the compressive strength and density of rubber concrete [32].

The feasibility of using crumb rubber tire in high strength concrete was studied by Thomas and Gupta [33]. They investigated that compressive, flexural tensile and pull-off strength of high strength concrete have a low decrease when the replacement percentage of crumb rubber is less than $10 \%$. A compressive strength close to $60 \mathrm{MPa}$ was measured for this concrete mixed with $0 \%$ to $12.5 \%$ crumb rubber. Other mechanical properties such as water absorption, depth of abrasion and depth of water penetration showed good results for mixes with up to $12.5 \%$ crumb rubber. For these reasons, these authors recommended using high strength concrete with crumb rubber aggregates for hydraulic structures like tunnels and dam spillways. Therefore, it is very important to limit the content of aggregates 
of waste rubber tire in concrete to avoid a high reduction of its mechanical properties such as the compressive and tensile strength. Other mechanical properties such as durability, abrasion and water absorption may be improved when the percentage of rubber tire waste increases. Thus, recycled tire rubber may be used for normal and high strength concrete mainly in secondary construction elements.

Table 1. Mix proportion $\left(\mathrm{kg} / \mathrm{m}^{3}\right)$ of the rubber concrete [32]. Copyright $\bigcirc$ 2017, Elsevier B.V.

\begin{tabular}{cccccc}
\hline Replacement \% & Cement (kg) & $\begin{array}{c}\text { Water in Liters } \\
(\mathbf{W} / \mathbf{c}=\mathbf{0 . 5 0 )}\end{array}$ & $\begin{array}{c}\text { Fine Aggregates } \\
\mathbf{( k g )}\end{array}$ & $\begin{array}{c}\text { Coarse } \\
\text { Aggregates (kg) }\end{array}$ & $\begin{array}{c}\text { Rubber } \\
\text { Aggregates (kg) }\end{array}$ \\
\hline $\mathbf{0 \%}$ & 364.81 & 225.17 & 610.43 & 1239.64 & - \\
$\mathbf{5 \%}$ & 437.77 & 224.2 & 590.03 & 1177.65 & 23.30 \\
$\mathbf{1 0 \%}$ & 437.77 & 224.2 & 590.03 & 1115.67 & 46.73 \\
$\mathbf{1 5 \%}$ & 437.77 & 224.2 & 590.03 & 1053.69 & 70.101 \\
$\mathbf{2 0} \%$ & 437.77 & 224.2 & 590.03 & 991.71 & 93.46 \\
\hline
\end{tabular}

Table 2. Physical properties of materials used as aggregates in the concrete [32]. Copyright@ 2017, Elsevier B.V.

\begin{tabular}{ccc}
\hline Material & Specific Gravity & Bulk Density $\left(\mathbf{k g} / \mathbf{m}^{\mathbf{3}}\right)$ \\
\hline Rubber aggregates & 1.10 & 650 \\
Fine aggregates & 2.6 & 1650 \\
Coarse aggregates & 2.8 & 1720 \\
\hline
\end{tabular}

Table 3. Compressive strength and density of concrete [32]. Copyright@ 2017 , Elsevier B.V.

\begin{tabular}{ccccc}
\hline \% of Replacement & Ultimate Load (kN) & $\begin{array}{c}\text { Compressive Strength } \\
(\mathbf{M P a})\end{array}$ & $\begin{array}{c}\text { Weight of Cubes } \\
(\mathbf{k g})\end{array}$ & Density $^{\left(\mathbf{k g} / \mathbf{m}^{\mathbf{3}}\right)}$ \\
\hline $\mathbf{0 \%}$ & 713.25 & 31.7 & 8.15 & $24,141.81$ \\
$\mathbf{5 \%}$ & 657.67 & 29.23 & 7.56 & 2240.702 \\
$\mathbf{1 0 \%}$ & 576.22 & 25.61 & 7.23 & 2143.14 \\
$\mathbf{1 5 \%}$ & 480.05 & 21.34 & 6.51 & 1928.88 \\
$\mathbf{2 0} \%$ & 373.72 & 16.61 & 6.34 & 1879.933 \\
\hline
\end{tabular}

The steel fibers from waste tires can be mixed with tire rubber to be used as aggregates of concrete combined with steel fibers from waste tires. Flores-Medina et al. [34] presented experimental results of thermal and mechanical properties of sustainable concrete. This concrete incorporated aggregates based on crumb rubber (CR) and steel fibers coated with rubber (FCR). The rubberized concrete with FCR had better bending and compressive strengths in comparison to concrete with crumb rubber. Furthermore, the concrete with FCR registered higher both energy of fracture and toughness than the concrete with crumb rubber. In addition, thermal conductivity showed the same decrement with waste rubber as aggregate with and without steel fibers. For these reasons, Flores-Medina et al. [34] proposed using fibers coated with crumb rubber for precast flat-roofs. Table 4 shows weight analysis of the main components of the two types of recycled rubber used in [34]. In addition, Table 5 indicates the mix proportions of the different concrete mixtures considered in [34]. Finally, Table 6 depicts the bulk density, bulk porosity, compressive strength, Young's modulus, bending strength, toughness and toughness index (TI) of concrete specimens with CR an FCR. Deviation factor (\%) is indicated between brackets. 
Table 4. Weight analysis of the main components of the two types of recycled rubber [34]. Copyright@ 2017, Elsevier B.V.

\begin{tabular}{ccc}
\hline Composition by Weight & FCR (\% Weight) & CR (\% Weight) \\
\hline Rubber & 50.35 & 96.90 \\
Textile fiber & 2.07 & 0.01 \\
Steel fiber & 5.04 & 0.00 \\
Rubber linked to steel fiber & 9.43 & 1.67 \\
Rubber + textile fiber + steel fiber & 5.81 & 0.01 \\
Rubber linked to textile fiber & 27.00 & 1.41 \\
Powder & 0.30 & 0.00 \\
\hline
\end{tabular}

Table 5. Mix proportions of the different concrete mixtures [34]. Copyright $\bigodot$ 2017, Elsevier B.V.

\begin{tabular}{|c|c|c|c|c|c|}
\hline Rubber & Cement $42.5 \mathrm{MPa}$ & Aggregate $4-8 \mathrm{~mm}$ & Recycled Rubber 4-8 mm & Sand $0-4 \mathrm{~mm}$ & Water \\
\hline $\begin{array}{l}\text { Substitution (CR and } \\
\text { FCR) (\% Volume) }\end{array}$ & $\left(\mathrm{kg} / \mathrm{m}^{3}\right)$ & $\left(\mathrm{kg} / \mathrm{m}^{3}\right)$ & $\left(\mathrm{kg} / \mathrm{m}^{3}\right)$ & $\left(\mathrm{kg} / \mathrm{m}^{3}\right)$ & $\left(\mathrm{kg} / \mathrm{m}^{3}\right)$ \\
\hline $0 \%$ (Ref. concrete) & 360 & 1103.0 & 0.0 & 722.8 & 180 \\
\hline $20 \%$ & 360 & 882.4 & 84.5 & 722.8 & 180 \\
\hline $40 \%$ & 360 & 661.8 & 169.0 & 722.8 & 180 \\
\hline $60 \%$ & 360 & 441.2 & 253.5 & 722.8 & 180 \\
\hline $80 \%$ & 360 & 220.6 & 338.1 & 722.8 & 180 \\
\hline $100 \%$ & 360 & 0.0 & 422.6 & 722.8 & 180 \\
\hline
\end{tabular}

Table 6. Bulk density, bulk porosity, compressive strength, Young's modulus, bending strength, toughness and toughness index (TI) results of concrete samples with CR an FCR. Deviation factor (\%) is indicated between brackets [34]. Copyright@ 2017, Elsevier B.V.

\begin{tabular}{|c|c|c|c|c|c|c|c|c|}
\hline Rubber & $\begin{array}{c}\text { Bulk } \\
\text { Density }\end{array}$ & $\begin{array}{l}\text { Ultrasonic } \\
\text { Modulus }\end{array}$ & $\begin{array}{c}\text { Bulk } \\
\text { Porosity }\end{array}$ & $\begin{array}{l}\text { Compressive } \\
\text { Strength }\end{array}$ & $\begin{array}{l}\text { Young's } \\
\text { Modulus }\end{array}$ & $\begin{array}{l}\text { Bending } \\
\text { Strength }\end{array}$ & Toughness & TI \\
\hline $\begin{array}{l}\text { Substitution } \\
\text { (\% Volume) }\end{array}$ & & (GPa) & $(\%)$ & (MPa) & (GPa) & (MPa) & $(\mathrm{kJ})$ & \\
\hline $\begin{array}{l}0 \% \text { (Ref. } \\
\text { concrete) }\end{array}$ & $2422(15.2)$ & $49.5(12.10)$ & $9.04(15.8)$ & 47.78 (12.6) & 8.88 & 4.75 (14.5) & 6970 & 1 \\
\hline $20 \% \mathrm{CR}$ & $2264(16.2)$ & $42.1(11.50)$ & 8.97 (15.9) & $27.71(15.3)$ & 5.91 & 3.75 (18.6) & 5500 & 1 \\
\hline $40 \% \mathrm{CR}$ & 2156 (17.5) & $31.2(9.80)$ & $9.29(18.2)$ & $17.71(16.8)$ & 3.93 & $2.90(17.8)$ & 2610 & 1 \\
\hline $60 \% \mathrm{CR}$ & $2026(14.5)$ & 27.5 (11.6) & $9.11(14.8)$ & $13.58(19.5)$ & 3.80 & $2.75(22.5)$ & 7120 & 1 \\
\hline $80 \%$ CR & 1858 (18.5) & $18.9(14.6)$ & $9.68(18.6)$ & $8.60(25.5)$ & 1.06 & $2.05(19.9)$ & 1490 & 1 \\
\hline $100 \%$ CR & 1742 (21.3) & $13.4(10.2)$ & $11.54(20.8)$ & $6.33(26.8)$ & 0.39 & $1.86(22.6)$ & 1810 & 1 \\
\hline $20 \%$ FCR & 2313 (17.5) & 44.0 (11.4) & $9.17(17.6)$ & 30.09 (18.9) & 5.71 & 4.30 (19.2) & 6120 & 1 \\
\hline $40 \%$ FCR & 2139 (16.4) & $34.4(16.5)$ & $11.38(16.8)$ & $22.84(19.5)$ & 4.63 & 3.43 (21.5) & 6280 & 3.70 \\
\hline $60 \%$ FCR & 2032 (17.1) & $28.5(17.8)$ & $14.01(17.9)$ & $15.82(20.6)$ & 3.60 & $3.32(20.3)$ & 3430 & 7.16 \\
\hline $80 \%$ FCR & 1851 (18.2) & $22.3(15.6)$ & 18.31 (17.9) & $9.60(20.5)$ & 2.05 & $3.24(28.5)$ & 8410 & 2.54 \\
\hline $100 \%$ FCR & 1668 (19.5) & $7.3(18.9)$ & $21.37(19.6)$ & $4.64(28.5)$ & 0.77 & $1.68(22.8)$ & 4910 & 1.56 \\
\hline
\end{tabular}

Although several studies have been carried out with rubberized concrete, more investigations are necessary that consider its microstructure and influence in corrosion behavior of reinforcement steel bars [35]. Furthermore, the mechanical behavior of rubberized concrete depends on the size range and percentage of the rubber particles. Figure 3 shows a comparison of several tire rubber particles with different size ranges and other aggregates used in rubberized concrete by [35]. It depicts small and large rubber particles from car tires with size up to $10 \mathrm{~mm}$ and $20 \mathrm{~mm}$, respectively. 

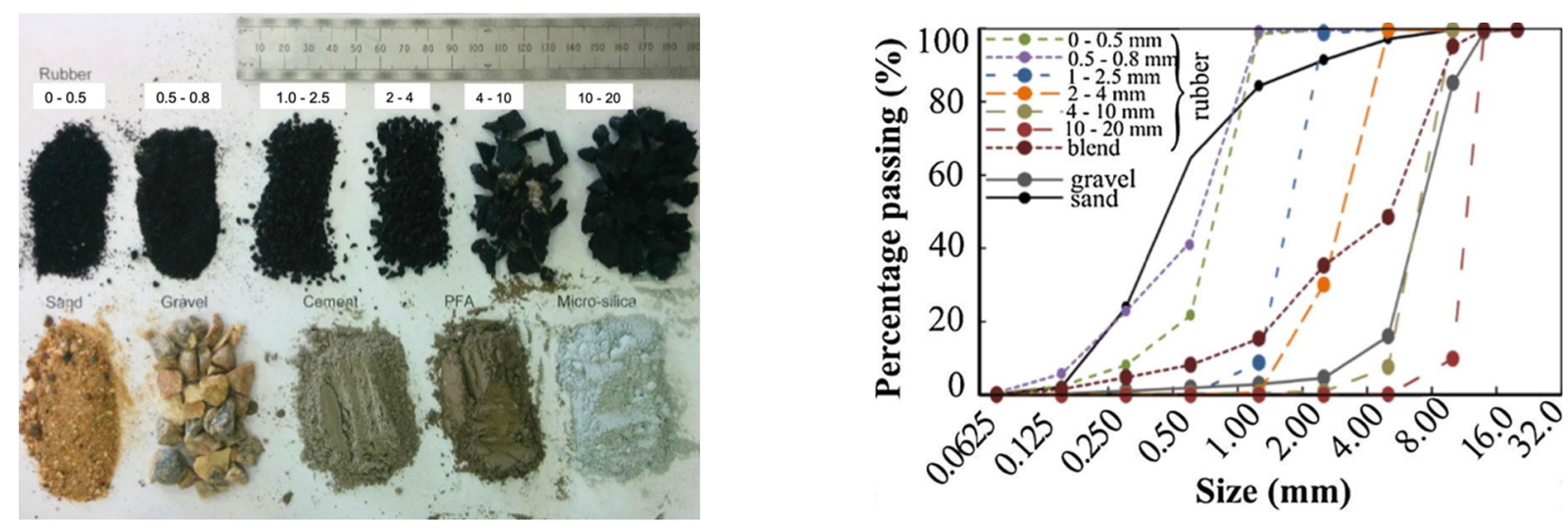

Figure 3. Comparison of tire rubber particles with other aggregates used in concrete mix. Reprinted with permission from [36]. Copyright@ 2019, Elsevier B.V.

\subsection{Recycled Plastic}

The global production of plastic products has achieved a continuous growth in the last 50 years. For instance, Law et al. [37] reported that the United States produced 42.0 million tons of plastic waste during 2016. The inadequately recycled and managed plastic waste can affect the ecosystems on the planet.

An alternative solution for the recycled of plastic waste can be its use in sustainable concrete. In this context, Dalhat and Wahhab [38] proposed to replace Portland cement by recycled plastic in proportions of 1:5 and 1:1, regarding a water-cement ratio of 0.36 . The recycled plastic concrete registered a compressive strength similar to asphalt concrete and sometimes similar to Portland cement concrete. However, the recycled plastic concrete had much less thermal sensitivity than the asphalt concrete. Choi et al. [39] studied lightweight aggregate obtained of waste polyethylene terephthalate (PET) bottles and used ground granulated blast-furnace slag (GBFS) to enhance its quality. The bulk density and specific gravity of the lightweight aggregate decreases close to $50 \%$ with respect to natural aggregate. The density and compressive strength (at 28-day) of the concrete with lightweight aggregate decreased when the replacement percentage and the water-cement ratio increased. For a replacement percentage of $75 \%$ lightweight aggregate, the structural efficiency of this recycled aggregate concrete was $21 \%$ lower in comparison with control concrete. Islam et al. [40] presented the effect of PET coarse aggregate on the compressive strength and workability of concrete. The 28 days compressive strength for the concrete with $20 \%$ PET aggregate at water-cement ratio of 0.42 achieved $30.3 \mathrm{MPa}$. It only decreased $9 \%$ with respect to the compressive strength of the natural aggregate concrete (NAC). Thus, small replacement percentage of PET can generate concrete with similar compressive strength of NAC. In addition, the workability of PET replaced concrete increased when both the replacement percentage and water-cement ratio increased. Lucolano et al. [41] evaluated the influence of the aggregates of polyolefin and PET waste on physical and mechanical behavior of six mortars. The recycled plastic aggregates improved the open porosity of the mortars, reducing their compressive and flexural strength. However, these aggregates generated up to $50 \%$ lower thermal conductivity of the mortars, which improved their thermal insulation behavior. This insolation behavior is suitable to control heat gain and heat loss from building during summer and winter, respectively. This mortar type can be employed for applications that do not need a structural performance. The use of recycled plastic aggregates in the production of hydraulic mortars can allow the development of ecosustainable building materials and decrease the environmental damage of plastic waste.

Based on regression analysis, Mohammed [42] proposed the following models (linear and power) to estimate the elastic modulus $\left(E_{c w}\right)$, the splitting tensile strength $\left(f^{\prime} t w\right)$ and flexural tensile strength $\left(f_{r w}\right)$ of concrete containing PET waste aggregate with a ratio from $0.4 \%$ to $75 \%$ as sand replacement. 
For the elastic modulus [42]:

$$
\begin{gathered}
E_{c w}=1.694+0.807 f^{\prime}{ }_{c w} \\
E_{c w}=0.229\left(f^{\prime}{ }_{c w}\right)^{1.4}
\end{gathered}
$$

where $E_{c w}$ and $f_{c w}^{\prime}$ have units of GPa and $\mathrm{MPa}$, respectively.

For splitting tensile strength [42]:

$$
\begin{gathered}
{f^{\prime}{ }_{t w}}=0.713+0.0826 f^{\prime}{ }_{c w} \\
{f^{\prime}{ }_{t w}}=0.246\left(f^{\prime}{ }_{c w}\right)^{0.75}
\end{gathered}
$$

For flexural tensile strength [42]:

$$
\begin{aligned}
& f_{r w}=1.36+0.11 f^{\prime}{ }_{c w} \\
& f_{r w}=0.317\left(f_{c w}^{\prime}\right)^{0.795}
\end{aligned}
$$

where $f_{r w}$ and $f_{c w}^{\prime}$ are measured in MPa.

The linear equations reported by Mohammed [42] were more accurate for calculating the elastic modulus and splitting tensile strength of PET replaced concrete. Although, the power equations registered better results for the flexural tensile strength of this sustainable concrete type. However, these equations must be adjusted for calculating the mechanical properties of concrete with other plastic aggregates.

Bui et al. [43] measured the mechanical properties and durability of concrete containing recycled woven plastic sack waste (RWS) and recycled PET bottles waste (RPET) fibers (see Figure 4). These recycled aggregates registered high resistance in alkaline solutions. After 180 days of immersion in alkaline environments of the RAC samples, the RWS and RPET fibers registered small variation between 0.07 and $0.6 \%$ with respect to that at 28 days. The RAC containing RPET aggregate and silica fume increased its compressive strength (3.6-9\%), shear strength (7-15\%), splitting tensile strength (11.8-20.3\%) and elastic modulus (16.9-21.5\%) with respect to RAC specimens without fibers.
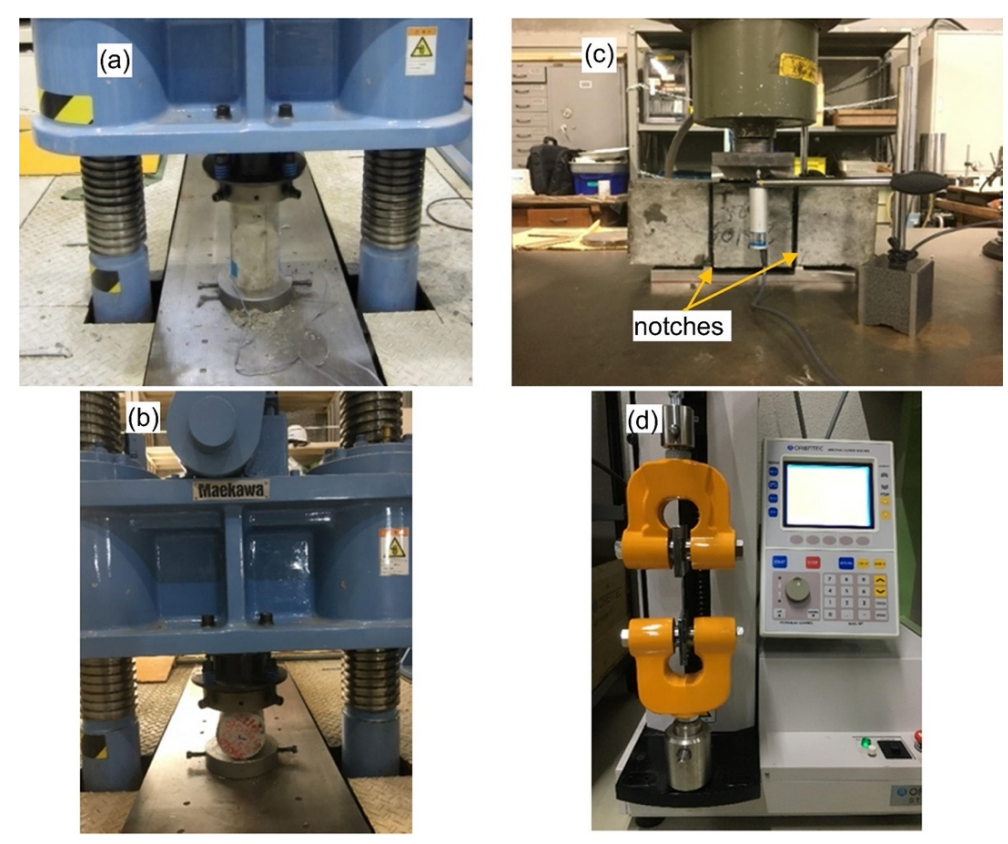

Figure 4. Experimental set-up for measuring (a) recycled aggregate concrete (RAC) compressive strength, (b) RAC splitting tensile strength, (c) RAC shear strength and (d) tension strength of recycled fiber. Reprinted with permission from [43]. Copyright@ 2018, Elsevier B.V. 


\subsection{Crushed Glass}

Glass is an abundant waste in domestic, commercial, electrical and car industries. This material is widely employed in containers, car glass, solar glass, blown glass and glass fiber [44]. It has various characteristics such as a transparent surface, abrasion resistance, durable and easy for manufacturing. The consumption of glass is growing due to the development of new glass-based products. The United Nations estimated that around two hundred million tons of waste are generated on the planet every year and glass waste represents $7 \%$ of this amount [45]. Generally, the behavior of concrete containing glass aggregate may increase its mixture workability, bleeding and segregation. However, this glass replaced concrete reduces its mechanical strength and drying shrinkage and increases its chemical and fire resistance as well as the carbonation resistance [46]. In order to monitor material microstructure and its adherence to the concrete mixture, it is necessary to obtain multiscale microscopic images with a scanning electron microscope (SEM) [46].

Cota et al. [45] evaluated the mechanical properties of concrete mixtures obtained by replacing Portland cement with metakaolin and quartz aggregate with waste glass to generate novel sustainable concrete tiles. Three hundred and ninety-six specimens were measured to determine the bulk density, permeability and dynamic modulus. Based on the test results (Figure 5), the specimens became lighter decreasing $2.87 \%$ of bulk density when the proportion ratio of glass increases to $15 \%$. Furthermore, the permeability of the concrete specimens increased $33 \%$ for $15 \%$ proportion glass. In addition, the dynamic modulus of the concrete specimens increased from $33.09 \mathrm{GPa}$ in the control concrete to $37.79 \mathrm{GPa}$ for specimen with $10 \%$ proportion glass.

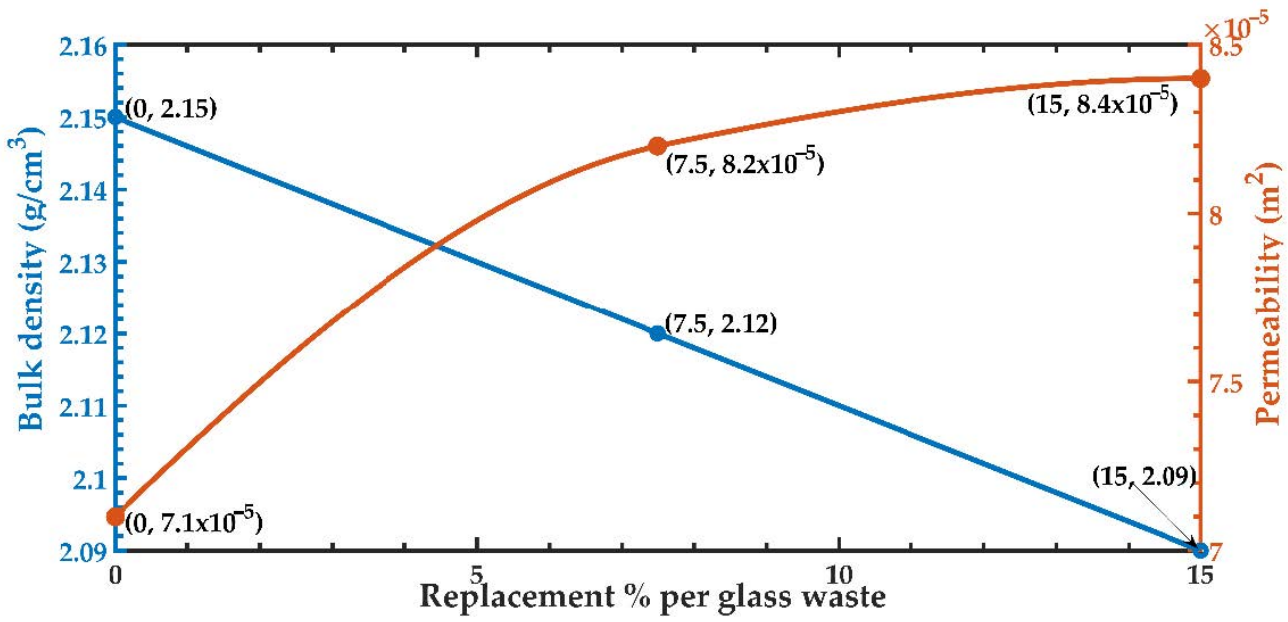

Figure 5. Results of bulk density and permeability versus glass particle fraction. Reprinted with permission from [45]. Copyright@ 2015, Elsevier B.V.

De Castro and De Brito [47] manufactured concrete by replacing construction aggregate with different mixtures of glass aggregate (fine and coarse) with percentage rate of $0 \%, 5 \%, 10 \%$ and $20 \%$. They measured the durability behavior of this concrete studding the water absorption through carbonation resistance, capillarity and immersion, chloride penetration and shrinkage tests. In addition, the effect of the size of the glass aggregates (GA) was evaluated in ten concrete samples. The results showed that the aggregate size has a high influence on the workability of the glass aggregate concrete (GAC). This workability of GAC had an increase for water-cement ratio between 0.55 and 0.58 and $20 \%$ percentage of fine GA. The density of GAC in a fresh state registered a small decrease when the percentage of glass aggregate increased. The compressive strength of the GAC was reduced with increasing the glass percentage. The water absorption of the GAC decreased between 14 and $24 \%$ for 5 and $10 \%$ replacement percentage of fine glass aggregate. In general, the GA do not significantly affect the durability behavior of GAC. Thus, the recycled GA is an 
option to be used in the construction sector, which helps in the reduction of the extraction of primary resources and the waste recycling.

For a self-compacting concrete based on the ASTM C1610-17 standard test method [48], Ali and Al-Tersawy [49] studied the influence of recycled glass fine aggregate (RGFA) on the properties of self-compacting concrete (SCC). They used 18 concrete samples at water-cement ratio of 0.4 and RGFA in replacement percentages of $0 \%, 10 \%, 20 \%, 30 \%$, $40 \%$ and $50 \%$. The splitting tensile strength, flexural strength, compressive strength and static modulus of elasticity of SCC containing RGFA decreased with increasing the FGFA percentage. For cement content of $450 \mathrm{~kg} / \mathrm{m}^{3}$, the 28 days compressive strength and splitting tensile strength of FGFA replaced SCC with proportion ratio of $10 \%, 20 \%, 30 \%$, $40 \%$ and $50 \%$ were decreased to $3.7 \%, 10.5 \%, 13.5 \%, 17.5 \%$ and $21 \%$, and $4.2 \%, 8.5 \%, 9.9 \%$, $12.7 \%$ and $22.5 \%$, respectively. For the same conditions, 28 days flexural strength and static modulus of elasticity of this concrete were decreased by $4.2 \%, 8.5 \%, 9.9 \%, 12.7 \%$ and $22.5 \%$, and $1.8 \%, 4.6 \%, 7 \%, 9.2 \%$, and $11 \%$, respectively. Furthermore, these authors found through SEM images that the amount of voids and cracks of this concrete increases with the percentage content of the RGFA.

Cassar and Camilleri [50] measured the mechanical properties of concrete containing crushed glass aggregate that replaced the cement in proportions from 10 to 50\%. For $10-40 \%$ crushed glass aggregate the compressive strength of concrete was close to $30 \mathrm{MPa}$ after 28 days and 90 days of curing. For this same aggregate percentage and days of curing, the flexural strength of the concrete was above $5 \mathrm{MPa}$.

Properties of glass powder-manufactured concrete were evaluated by Saribiyik et al. [51]. Figure 6 depicts the behavior of compressive and flexural strength of concrete samples with glass powder aggregate as function of proportion ratio of glass powder aggregate. These mechanical properties are adjusted to an exponential mathematical model with an $\mathrm{R}^{2}$ value of 0.60 for flexural strength and $\mathrm{R}^{2}$ value of 0.49 for compressive strength. The highest compressive strength and flexural strength were achieved with $30 \%$ replacement of glass powder aggregate in cubes of $40 \mathrm{~mm} \times 40 \mathrm{~mm} \times 160 \mathrm{~mm}$. Both compressive and flexural strength were reduced for replacement percentage of glass powder higher than $30 \%$. In addition, the volumetric weight in the control concrete sample decreased to $1914 \mathrm{~kg} / \mathrm{cm}^{3}$ from $1935 \mathrm{~kg} / \mathrm{cm}^{3}$ with $47 \%$ replacement of glass powder. There is a decrease in volumetric weight of the concrete leading to a lighter material. Therefore, it is recommended to find the optimum content of glass waste replacement.

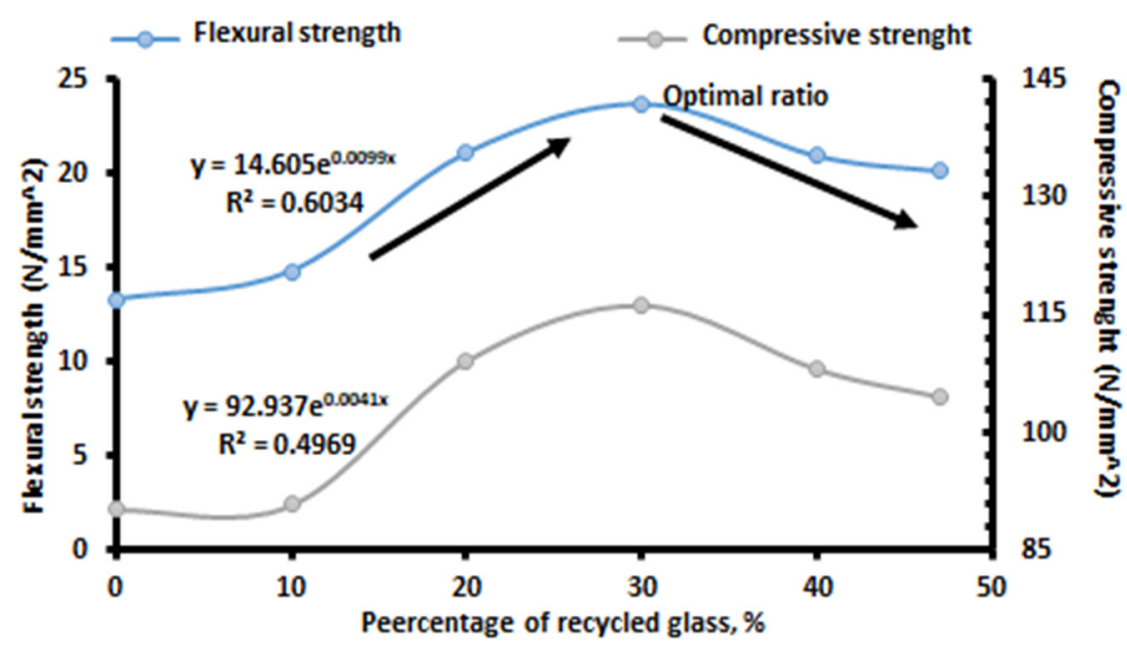

Figure 6. Flexural and compressive strength behavior of concrete samples with glass powder. Reprinted with permission from [51]. Copyright $\subset$ 2013, Elsevier B.V.

Afshinnia and Rangaraju [52] evaluated the effect of ground glass powder (GCP) used to replace the cement or aggregate on the mechanical properties of Portland cement concrete. In addition, they investigated the impact of combinations of glass powder with 
crushed glass aggregate or natural mineral aggregate on the properties of concrete samples. They employed $80 \%$ of crushed glass aggregate and $20 \%$ of GGP. The concrete samples were handled accordingly to the ASTM C192 standard test method. The 28 days compressive strength of the concrete containing $20 \%$ glass powder as cement replacement decreased $13.7 \%$ with respect that of the control sample $(27.0 \mathrm{MPa})$. On the other hand, 28 days compressive strength of the concrete containing content of $20 \%$ glass aggregate increased $25.93 \%$ in comparison with control sample. Soliman and Tagnit-Hamou [53] reported the behavior of sustainable ultra-high-performance glass concrete (UHPGC) containing glass powder aggregate that was generated from recycled glass culets (see Figure 7). This glass powder aggregate was employed to replace cement and quartz powder in typical UHPC. This can help to reduce the $\mathrm{CO}_{2}$ emissions, costs and carbon footprint of conventional UHPC as well as conserve natural resources. They used content of $10 \%, 20 \%, 30 \%, 40 \%$ and $50 \%$ of glass powder aggregate in conventional UHPC. The higher proportion ratio of glass powder aggregate causes greater workability of the UHPGC. This concrete type reduced its maximum heat flow and total heat. In addition, the UHPGC offers accelerated hydration kinetics for content of glass powder up to $20 \%$.

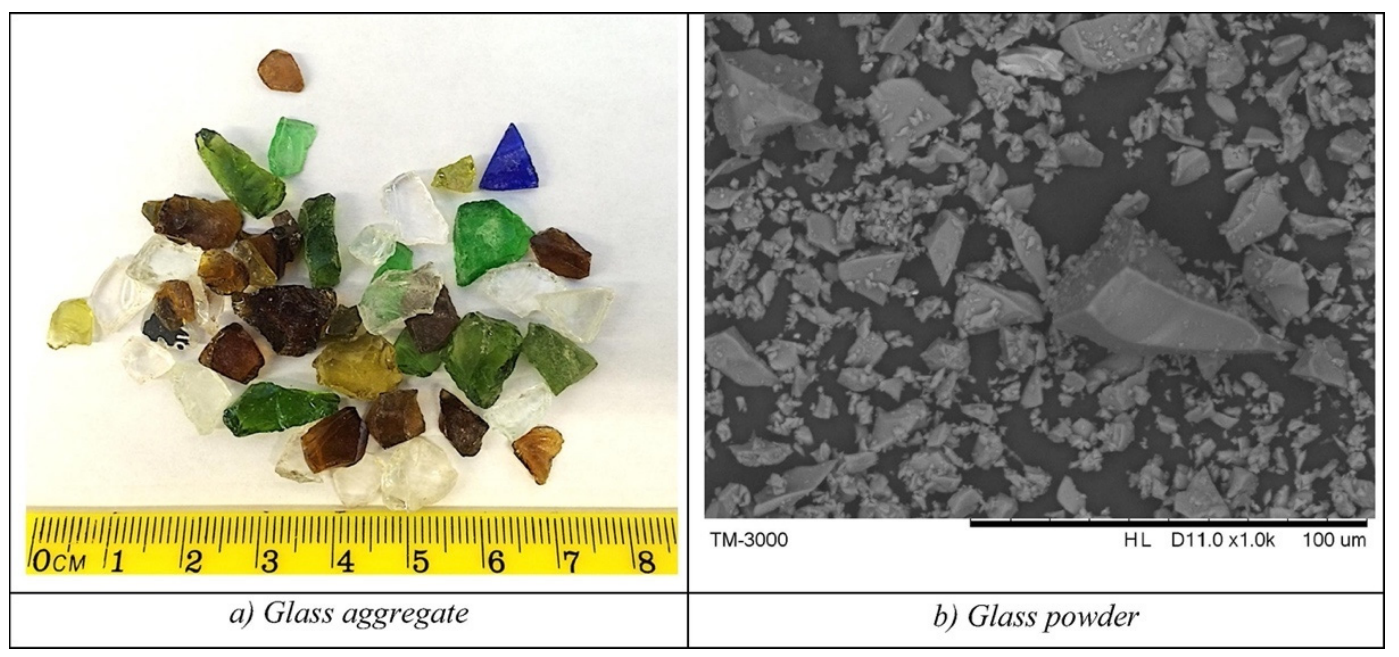

Figure 7. Example of crushed glass using for improving concrete properties. Reprinted with permission from [52]. Copyright $($ 2016, Elsevier B.V.

\subsection{Blocks Manufacturing}

Lee et al. [54] registered the effect of the proportion ratio and size range of recycled fine glass (FG) aggregates on the properties of concrete blocks. They test 17 blocks of $70 \mathrm{~mm} \times 70 \mathrm{~mm} \times 70 \mathrm{~mm}$ with different mixtures using content of $25 \%, 50 \%, 75 \%$ and $100 \%$ of FG. The 28 days compressive strength of concrete blocks containing $100 \%$ FG aggregate (size $<600 \mu \mathrm{m}$ ) increased up to $58.44 \mathrm{MPa}$ in comparison with control concrete (43.51 MPa). Concrete blocks incorporating $25 \%$ and $100 \%$ FG aggregate with unsieved particle size decreased $8.8 \%$ and $11.5 \%$ their 28 days compressive strength. Chidiac and Mihaljevic [55] implemented tests in concrete blocks adding waste glass powder (WGP) that replaces to cement. The compressive strength of the blocks was measured after of 4 , 160 and 365 days. The water absorption of concrete blocks showed a small increase due to the incorporation of WGP. The 4-day compressive strength of the blocks incorporating $10 \%$ and 25\% WGP registered the strength above $12 \mathrm{MPa}$. The blocks with 25\% WGP do not increase the compressive strength from 160 to 365 days.

The recycled glass used as aggregate in concrete blocks can reduce their mechanical properties [56]. In order to use recycled glass in concrete blocks is important to determine its optimum replacement content to achieve the better compressive and flexural strength without affect the concrete workability. 


\subsection{Industrial Waste}

A sustainable concrete is obtained by employing industrial recycled materials, helping the reduction of greenhouse gases and decreasing the impact of global warming [57]. To replace Portland cement or aggregates, various types of waste may be used such as sand, casting waste, steel slag, cupper slag, slag from smelting processes, coal ash, ferrochrome slag and palm oil [58].

Prusty et al. [10] presented a review about agroresidual waste, which are employed as a partial replacement of fine aggregate in concrete. This review reported the properties of fresh and hardened concrete as well as its durability, thermal conductivity, compressive strength, flexural strength and elastic modulus. It considered the properties of concrete that contains agro-alimentary waste and self-compacting mortars, and the properties of several agroresidual materials (i.e., peanut shells, oyster shells, cork, rice hull ashes, tobacco waste, bagasse ashes and sawdust ashes).

De Almedia and Zulanas [59] carried out a research about the implementation and feasibility of hazardous waste (muds), which are produced of water purifying systems, in the manufacture of concrete. This can preserve the environment and reduce costs of aggregate used in concrete. Five percent of mud content as aggregate can be used in constructions that do not need a high mechanical strength as sidewalks and concrete pathways.

Lee et al. [60] studied the use of mud products of integrated circuits industries, which contain hazardous materials of silicon oxide, aluminum oxide and calcium fluoride. The compressive strength, stress-strain and elastic modulus of samples after the curing days $(7,14,28,56$ and 91 days) were compared with control sample. Properties of the fresh sample (weight, air and chloride content) had a similar behavior. Based on these results, an efficiency of its use can be demonstrated within the construction industry.

Ceramic powders can have pozzolanic activity and be used as a cementing agent or as aggregate in concrete. Rashid et al. [6] researched a sustainable concrete employing ceramic waste and evaluating its efficiency as a replacement of aggregate to conserve natural resources. The results show that concrete with $30 \%$ replacement proportion generates high compressive strength and a lesser impact to the environment and an option for a sustainable concrete. Concrete samples of cubes $(150 \mathrm{~mm} \times 150 \mathrm{~mm} \times 150 \mathrm{~mm})$ were evaluated. The water absorption of the samples was increased when the ceramic waste percentage increased. The water absorption of the concrete sample containing $30 \%$ replacement of ceramic waste achieved $11.18 \%$, which was higher than that $(7.84 \%)$ of the conventional concrete. This increase in the water absorption capacity is due to the clay quality. On the other hand, the workability of the samples was reduced $10.2 \%$ with the increase of the ceramic aggregate quantity. In addition, the compressive strength of the samples increased with the time in all mixtures and always was higher than the control specimen measured after 28 and 63 days. The concrete volume was linearly reduced up to $17 \%$ with $30 \%$ replacement of ceramic waste [6].

Torres et al. [8] studied the effect of casting waste as aggregate material on the properties of concrete. For replacement proportions up to $30 \%$ with fine and coarse casting waste aggregates, there is no impact on mechanical properties (compressive strength, flexural strength, splitting tensile strength and elastic modulus) of the concrete after of 28 days. Thus, the partial use of casting waste in concrete can be used to save natural resources and increase the recycling of this material.

Sharmila and Dhinakaran [61] measured concrete compressive strength and porosity properties employing ultra-fine slag. For $10 \%$ proportion of ultra-fine slag incorporated in concrete, optimum conditions of compressive strength and durability of the concrete were obtained. The compression strength of the concrete was determined in cubes $(100 \mathrm{~mm} \times 100 \mathrm{~mm} \times 100 \mathrm{~mm})$. This strength was $53.4 \mathrm{MPa}$ for the control specimen and $51.8 \mathrm{MPa}$ for the concrete with $10 \%$ replacement of ultra-fine slag (RUFS). The compressive strength of the samples registered small reductions for the $5 \%, 10 \%$ and $15 \%$ proportions of (RUFS) after of 7, 28, 56 and 90 days of curing. 
Analyzed industrial waste displays different behaviors regarding physical and mechanical properties. Therefore, it is necessary to analyze a specific material and evaluate its feasibility within the construction industry. The employment of industrial waste in cementing agents or aggregates contributes to the preservation the environment.

\section{Synthetic Fibers}

\subsection{Steel Fibers}

Steel fiber is usually recovered from scrap tires and used to produce steel fiber reinforced concrete (SFRC). The mechanical properties of SFRC can be affected by factors such as water-cement ratio, steel fiber geometry, steel fiber volume fraction and ratio aspect and curing time [62]. Based on the investigation of Biskri et al. [63], the steel slag aggregate incorporated in high performance concrete (HPC) can improve its mechanical strength and durability. However, high expansion steel slag should not be used in concrete constructions without any treatment of free oxides to decrease its expansion capacity [63].

Sengul [64] reported that the percentage of waste steel fibers added in concrete affects its workability. Although, compressive strength of this concrete is not significantly affected. $\mathrm{Yu}$ et al. [65] researched concrete samples with different types of aggregates such as steel slag and waste glass. They demonstrated that these aggregates can improve the fire resistance of the concrete samples. Pogorelov and Semenyak [66] studied the frost resistance of concrete using steel fibers as reinforcement and established that steel fibers can enhance the strength and durability to cracking even under freezing temperatures. Another type of steel fiber (steel slag and steel sludge) in concrete was used by Roslan et al. [67]. The steel slag and steel sludge were generated from the melting process of metal scrap and steel wire production, respectively. They identified the composition of the fibers using X-ray fluorescence and X-ray diffraction tests. The incorporation of these fibers in concrete improved its compressive strength, achieving the best strength with $10 \%$ replacement of steel slag. They recommended to use up to $15 \%$ steel sludge and $20 \%$ steel slag in concrete.

Generally, reinforcing fibers have been used to reduce cracking in structural elements [68]. The inclusion of fibers in conventional reinforced concrete can improve the structural and functional performance of structures, for instance, pressurized structures such as pressure tanks, steel and polyamide fibers. The pressure capability can be greatly improved by adding steel and polyamide fibers to conventional reinforced concrete. Steel fibers are more effective when improve the containment performance of a prestressed concrete containment vessel (PCCV) in comparison to polyamide fibers. Fiber reinforcements have effectiveness at high loading pressure and low prestress level. These fibers can be used in structural elements such as beams and columns, which are extensively studied due to the exhibited tensile strength and postcracking deformation capacity. Concrete elements reinforced with steel fibers present correlations, according to the guidelines established by the ACI-318, which allow the estimation of basic mechanical properties of steel-reinforced concrete [69].

Figure 8 shows the steel fibers incorporating in concrete to decrease its cracking. The mechanical behavior of concrete with steel fibers are evaluated to identify the optimal replacement ratio that improves its mechanical properties. The steel fibers can improve the maximum strain and shear behavior of recycled aggregate concrete beams [70]. 


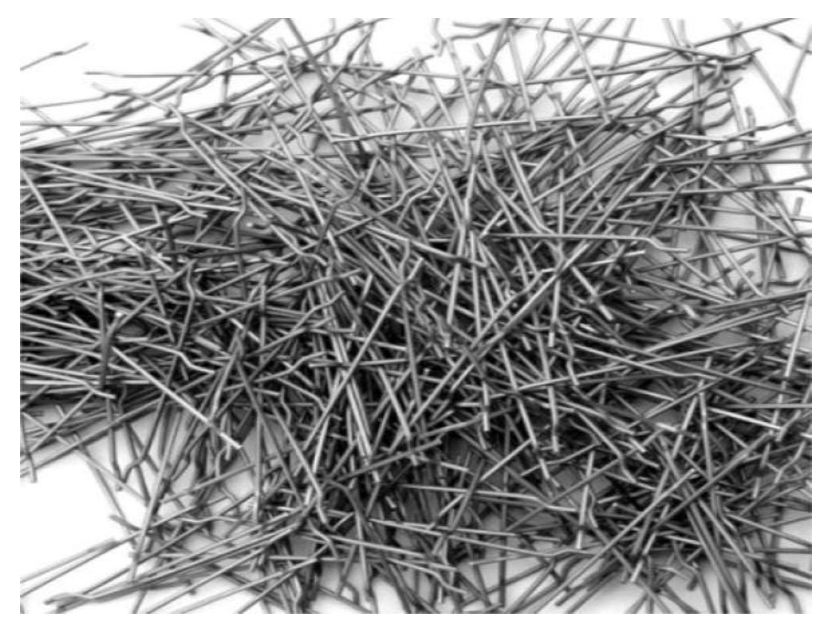

Figure 8. Steel fibers can be used for reducing cracking in concrete. Reprinted with permission from [70]. Copyright@ 2019, Elsevier B.V.

\subsection{Glass Fibers}

Glass fiber is a type of fiber reinforced plastic, containing silica or silicate and can be used in architectural elements but also subjected to mechanical forces. Thus, these elements also show deformations and cracks.

Ali et al. [71] studied the mechanical behavior of concrete specimens added with different volumes of glass fiber and concrete waste aggregate (CWA). For 30\%, 50\% and $100 \%$ content of CWA, the concrete at $0.25-0.5 \%$ glass fiber measured its maximum results of compressive strength, flexural strength and elastic modulus. In comparison with control specimen, the compressive strength, flexural strength and elastic modulus increased at $1.5-7 \%, 0.5-5 \%$ and $19-25 \%$, respectively. Moghadam et al. [72] investigated the impact of steel and glass fiber incorporation on the durability and mechanical performance of concrete samples at high temperatures from $28{ }^{\circ} \mathrm{C}$ to $800{ }^{\circ} \mathrm{C}$. The steel fibers enhance the compressive, tensile and shear strength of the concrete at $9-27 \%, 8-198 \%$ and $1-22 \%$, respectively. For concrete samples with inclusion of glass fiber, the compressive and tensile strength improved at $1-18 \%$ and $19-213 \%$, respectively.

Mastali et al. [73] reported the impact strength and mechanical properties of selfcompacting concrete samples reinforced containing recycled glass fiber reinforced polymers (GFRP). These samples were obtained with $0.25 \%, 0.75 \%$ and $1.25 \%$ content of fiber. The incorporation of the glass fiber in the concrete samples improved their impact resistance and mechanical properties. In addition, these authors developed equations to correlate this impact resistance of the concrete samples to the mechanical properties considering high magnitudes of coefficient of determination. On the other hand, the use of glass fiber and nylon fibers in concrete to prevent microcracks in bridge decks has been studied by Khan and Ali [74]. They added glass fibers and nylon fibers in concrete specimens. After compressive tests, they registered that the number of cracks, crack width and length are more in plain concrete compared to concrete containing glass fiber and nylon fibers.

The glass fibers can be used as rods in a wide range of applications in civil construction as reinforcement of concrete support elements. These rods based on glass fiber can have greater bearing capacity with respect to steel rods. However, it is not recommended to replace steel rods with those of glass fiber considering only their diameter. More technical information of the rods is required to ensure similar mechanical behavior [75].

\subsection{Carbon Fiber Reinforced Polymers}

FRP sheets retrofit reinforced concrete elements FRP composite materials such as carbon fiber reinforced polymers (CFRP) are applied to reinforced concrete structures by either externally bonded reinforcement or near surface mounted techniques. The latter considers the insertion of the CFRP into grooves opened on the concrete cover 
giving as a result the largest ratio of bond area of the CFRP bar and higher confinement provided by the surrounding concrete. This improves the structural behavior of CFRP strengthened concrete element in shear and flexure compared with CFRP elements bonded near surface [76]. Unfortunately, CFRP laminates in any bonded technique can ensure enough ductility in beams to be used in seismic zones [77]. In fact, experimental tests carried out by Tahsiri et al. [78] in CFRP strengthened beams showed premature debonding failure at the midspan even with the use of U-wrap transverse FRP perpendicular to the longitudinal axis in the location of the supports. Instead, they recommended using reinforced concrete jacketing, which gets a higher ductility in the same performed tests.

In contrast to the low ductility obtained with CFRP in beam structures, several studies have demonstrated that the use of circumferential FRP wrapping in columns increases both strength and ductility [79-81]. Furthermore, high-strength concrete, which normally exhibits a fragile failure, can be used in columns of structures located in seismic zones if their potential hinge regions are externally bonded with CFRP wraps. Ductility and energy dissipation capacity can be significantly improved if the confined area at the plastic hinge region is larger than 1.1 times the cross-section diameter [81]. Although several studies have been developed with FRP composite material in concrete, more research is necessary into topics such as bonding CFRP in concrete surface, which also will increase CFRP strengthened beams.

\subsection{Textile Fibers and Reinforcements}

Textiles mixed in concrete are materials with appropriate mechanical properties that can reduce the density and costs of the concrete, helping in the reduction of the $\mathrm{CO}_{2}$ emissions. These materials are sustainable solutions in structural reinforcement and structural reconditioning elements in civil engineering constructions [82,83].

Kong et al. [82] compared the durability of textile reinforced concrete (TRC) using tensile and flexural loads after 14, 90 and 120 days. TRC specimens were prepared with two different proportions with 2 to 6 glass fiber layers. Based on the results, fibers were subjected to flexural strength without find differences within the microstructure. Slight fractures were observed on the specimens' surface. After 90 days, an increase in tensile and flexural strength were observed. In addition, a decrease in ductility was measured in the speeding process of the specimens' age.

D'Antino and Papanicolaou [83] evaluated the tensile strength of high resistance textiles incorporated within inorganic matrixes. Six different fiber types were embedded in cement matrixes, including carbon, glass, basalt and steel cables. The $500 \mathrm{~mm}$ long fiber was subjected to a tensile strength test according to guidelines of ASTM D3039. The mechanical properties were characterized in the cementing matrix in 32 rectangular prisms. In these tensile strength tests, three failures were registered: a major crack near the specimen fastening, a major crack in the greatest fastening zone and a crack near the fastening with textile slipping within the matrix.

De Santis et al. [84] developed relevant data about test methods for textile reinforced mortars. They employed textile reinforced mortar instead without epoxy resins to provide a better behavior under high temperatures and a quick and easy installation. In addition, it does not generate risks for the workers due to toxic volatile compounds. The tensile strength tests were carried out in prismatic specimens with a rectangular cross-section, which have one or more fiber layers embedded in the mortar matrix. The samples were curing at 28 days and their stress-strain behavior was characterized with three response stages (uncracked, fracture development and cracking).

Textile reinforced concrete allows sustainable building material with good mechanical behavior for structural elements and architectural components. A potential application of TRC are the thin structural elements such as shell, laminar or folded components. In addition, TRC is suitable for prefabricated structural components. Due to its low thickness, TRC has low weight and can be transported and assembled on site. In addition, the 
TRC-based structural components can be used in demountable, modular and reusable systems [85].

Jing et al. [86] investigated the compressive behavior of TRC-confined masonry columns. In addition, they developed equations to estimate the compressive strength and ultimate strain of TRC-confined masonry columns considering the experimental data. The samples confined with the carbon-glass TRC improved the ductile performance in comparison with that of the basalt-glass TRC. The equations of Jing et al. [86] to predict the compressive strength of TRC-confined masonry columns agreed well with the experimental results. However, the equations to calculate their ultimate strain presented a lower accuracy.

Sustainable development continuously is growing within the construction industry. TRC represents an innovative material that increases mechanical properties of concrete. It has been a subject of research and models have been created regarding fiber incorporated to concrete to demonstrate its efficiency. For instance, Figure 9 depicts waste cotton fibers, obtained from blue-jeans, which were incorporated to polyester concrete [87].

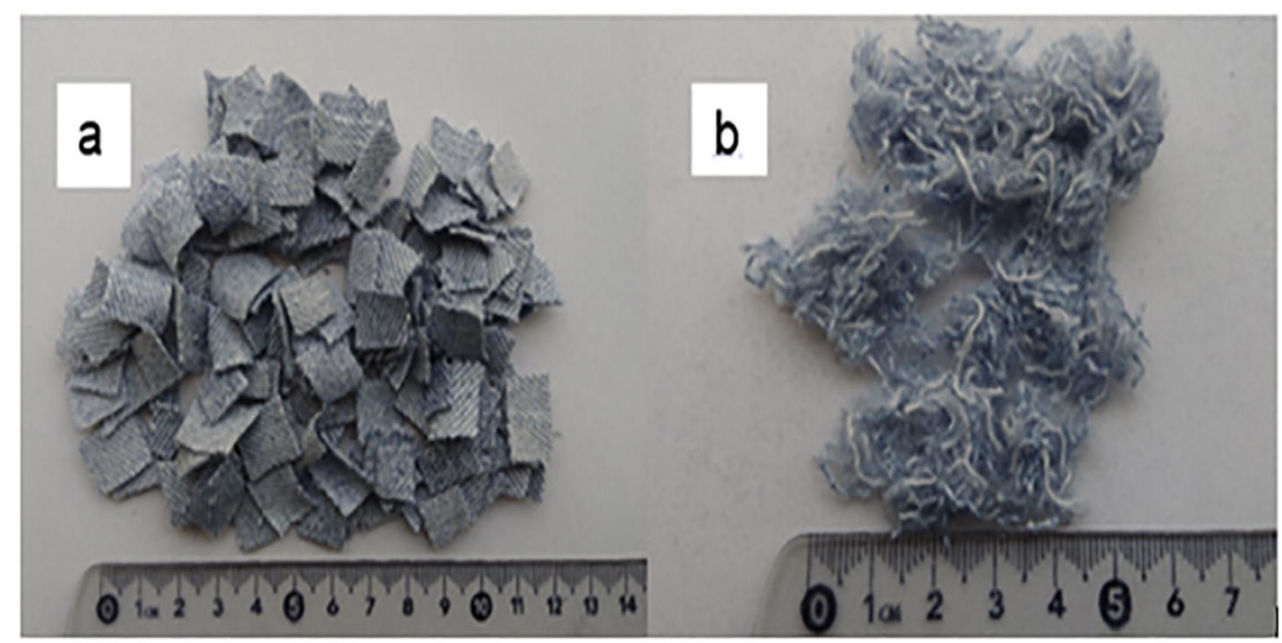

Figure 9. Textile waste can be used to improve some properties of concrete: (a) waste blue-jeans and (b) cotton fiber from blue-jeans. Reprinted with permission from [87]. Copyright $\odot 2018$, Elsevier B.V.

\subsection{Epoxy Resins}

Epoxy resins are materials that mixed with concrete can increase its compressive and tensile strength as well as the elastic modulus. These materials have workability and segregation reduction advantages. The concrete containing epoxy resin increases its ductility and reduces the permeability and contraction. Furthermore, this concrete type offers corrosion resistance [88]. Due to the adhesion properties and chemical resistance, the epoxy resins have been used as adhesive materials and corrosion resistant paints in the construction industry. Agnostopoulos et al. [88] measured the properties of epoxy resin mortar resistance considering different grout proportions mixed with epoxy resins $(0 \%, 5 \%$ and $30 \%$ dosages). The highest values of compressive, flexural and tensile strength were observed in modified mortars with $30 \%$ epoxy resin dosage. The epoxy resin increased the compressive strength, splitting tensile strength and elastic modulus by up to $21 \%, 84 \%$ and $190 \%$, respectively, after 28 - and 90 -day of curing. Furthermore, the toughness and resistance to acid erosion of epoxy resin-modified gouts were significantly improved when epoxy resin dosages increased.

Ariffin et al. [89] evaluated the resistance properties of modified mortars with bisphenol A-type epoxy resin (5\%, 10\%, 15\% and 20\% dosages). These mechanical properties were measured in wet-dry and dry curing conditions. The maximum compressive strength, tensile strength and flexural strength were achieved with the epoxy resin dosage of $10 \%$. After 28 days of curing, the highest compressive strength and flexural strength were 36 
and $3 \mathrm{MPa}$, respectively. Furthermore, the water absorption decreased as the epoxy resin percentage increased.

Ferdous et al. [90] added epoxy resin in concrete employed in railway sleepers to study its physical and mechanical properties as well as reduce its costs. To conserve a suitable balance between physical and mechanical properties and cost, the mixes adding fillers from $30 \%$ to $50 \%$ could be a good option for coating of composite railway sleepers. Proportions greater than $60 \%$ substantially increased the concrete porosity. In addition, density of concrete is increased with an epoxy polymer by $33.9 \%$ using the proportions from $0.0 \%$ to $60 \%$.

Toufigh et al. [91] studied the compressive and tensile behavior of a new polymer concrete. This concrete exhibits low shrinkage, good chemical resistance, high durability, corrosion resistance and excellent adhesion characteristics. Compressive resistance tests were carried out according to the guidelines established by the ASTM D695 (American Society for Testing and Materials, West ConshohockenCity, PA, USA). The maximum strength was two to three times greater than the control sample. The compressive and tensile strength were kept constant when the amount of epoxy resins was increased. In addition, elastic modulus improved for higher proportions of epoxy resins.

Epoxy resins have been used in asphaltic concrete, displaying results with excellent strength properties, high temperature stability and fatigue resistance. Zhong et al. [92] measured the surface properties of asphaltic concrete with epoxy resins, obtaining a permeability of $7.7 \times 10^{-5} \mathrm{~mm} / \mathrm{s}$. It is a very low value mainly as a result of low air voids in asphaltic concrete with epoxy resins.

Epoxy resins can improve the resistance in mortars manufacture but had no effect in the construction of structural elements such as railway sleepers, where concrete resistance properties decreased. However, the epoxy resins can increase the permeability properties and fatigue resistance. Epoxy resins allow creating new concretes that improve the chemical and mechanical resistance characteristics. Although, more experiments are required to corroborate the efficiency of the epoxy resins in specific structural elements.

\subsection{Mineral Fibers}

Mineral additives are the most prospective components for concrete in the development of new materials within the construction industry such as high resistance concrete and special absorbents of heavy metals. These minerals can be zeolite, silicon dioxide and micro dust. Nagrockiene and Girskas [93] studied the compressive strength of concrete containing natural zeolite with dosage from 0 to $10 \%$. Regarding the compressive strength, tests were carried out in specimens $(100 \mathrm{~mm} \times 100 \mathrm{~mm} \times 100 \mathrm{~mm})$ after 28 days of curing. Zeolite with $10 \%$ content increased the compressive strength of concrete by $15 \%$ and decreased water absorption by 2.3 times. In addition, the density and ultrasonic pulse velocity of the concrete were increased. In addition, zeolite replaced concrete improved 3.3 times the freeze-thaw resistance of concrete with up to $10 \%$ of zeolite content.

Markiv et al. [9] investigated the mechanical and durability properties of zeolite reinforced concrete (ZRC). This concrete incorporated 10\% natural zeolite and superplasticizer. The replacement of cement by zeolite caused a reduction of ZRC compressive strength until 90 days of hardening; although, after 180 days compressive strength of ZRC was higher compared with concrete without zeolite. Concrete with zeolite increased the freeze-thaw resistance and durability and decreased the drying shrinkage and water penetration depth.

Aggregates and powder obtained from marble and granite are considered waste materials. Granite is commonly used as ornamental rock and construction material. Sharma et al. [2] used polished granite waste recycled from discarded tiles as aggregate in concrete samples. They determined the effect of the granite powder on the mechanical properties and absorption of granite replaced concrete. This granite powder caused a reduction of the compressive, flexural tensile and pull-off strength of the concrete. However, concrete containing granite powder showed better performance for water absorption, abrasion and water permeability. Sharma et al. [2] recommended to use concrete with up to $20 \%$ of 
natural coarse granite for structural applications and concrete containing from $20 \%$ to $40 \%$ for nonstructural components and pavement.

Elmoaty [14] reported the physical, mechanical properties and corrosion behavior of concrete samples containing granite dust with dosages of $5 \%, 7.5 \%, 10 \%$ and $15 \%$, respectively. The best content of granite dust was $5 \%$ after 56 days of water curing, in which the compressive strength and tensile strength of the granite replaced concrete increased $8.2 \%$ and $5 \%$ compared with concrete without granite dust. Furthermore, granite dust with up to $7.5 \%$ content registered insignificant impact on corrosion resistance of concrete containing granite dust.

Popek et al. [94] evaluated the properties of modified concrete with quartz mineral powder, obtaining better behavior with $20 \%$ replacement of this mineral. Physical properties of concrete are influenced by mineral powder. The bulk density increased as the mineral increased from $2.01 \mathrm{~g} / \mathrm{cm}^{3}$ (control specimen) to $2.19 \mathrm{~g} / \mathrm{cm}^{3}$ with $20 \%$ content of quartz mineral powder.

Atutis et al. [95] carried out an experimental study of basalt fiber reinforced concrete for prestressed beams under cyclic loading. The elastic modulus decreased by $4 \%$ after applying 1 million cycles. The compressive strength was measured in rectangular beams of $3.2 \mathrm{~m}$ long, $150 \mathrm{~mm}$ wide and $300 \mathrm{~mm}$ high, showing a variation of results from 40.2 to $46 \mathrm{MPa}$. Furthermore, Sardinha et al. [96] investigated the concrete durability with fine aggregate of marble mud, which decreased with this material.

Mineral additives represent a potential to enhance concrete. These minerals can be obtained from different types of rock and used as coarse or fine aggregate. However, more investigations are necessary to obtain precise data about the efficiency of the mineral aggregates in concrete.

Table 7 shows the most significant properties of each treatment used in the improvement of concrete using synthetic fibers.

Table 7. Some treatments with the most significant properties of synthetic fibers.

\begin{tabular}{|c|c|c|}
\hline Type of Treatment & Properties & Reference \\
\hline $\begin{array}{l}\text { Steel fibers recovered } \\
\text { from tire waste }\end{array}$ & $\begin{array}{l}\text { The use of fibers affects the mechanical properties of concrete, affecting the toughness of } \\
\text { the concrete. } \\
\text { Use of waste fibers can optimize to produce reinforced concrete. }\end{array}$ & {$[64]$} \\
\hline Steel fibers & $\begin{array}{l}\text { As the content of steel fibers increases, the compressive strength of concrete decreases to } \\
\text { an almost constant value. } \\
\text { The modulus of elasticity decreases as the content of steel fibers increases. } \\
\text { The Poisson's modulus decreases to a nearly constant value as the steel fiber } \\
\text { content increases. }\end{array}$ & [69] \\
\hline $\begin{array}{l}\text { Fiberglass Reinforced } \\
\text { Ceramic Concrete }\end{array}$ & $\begin{array}{l}\text { Resistance to compression, flexion and shear toughness increased with increasing fiber. } \\
\text { Workability decreased with increasing fiber. } \\
\text { Adding fiberglass modified the elastic modulus very little. }\end{array}$ & [72] \\
\hline $\begin{array}{l}\text { Textile-reinforced } \\
\text { concrete }\end{array}$ & $\begin{array}{l}\text { The durability of concrete against aging processes is compared. } \\
\text { From tensile tests, changes in the stress-strain behavior are observed in the } \\
\text { development of the cracking pattern. }\end{array}$ & [82] \\
\hline $\begin{array}{l}\text { Epoxy resin } \\
\text { (bisphenol A-type) }\end{array}$ & $\begin{array}{l}\text { Produces high resistance to compression and flexural stress with an addition of } 10 \% \text {. } \\
\text { The workability of the concrete decreases after } 10 \% \text { replacement. }\end{array}$ & [89] \\
\hline Epoxy polymer & $\begin{array}{l}\text { They decreased the physical, mechanical properties and durability with } 30 \text { to } \\
50 \% \text { replacement. } \\
\text { The density of the polymer increased by } 33.9 \% \text {. } \\
\text { The porosity of the mixture is generally low. }\end{array}$ & [90] \\
\hline $\begin{array}{l}\text { Epoxy resin in concrete } \\
\text { pavement }\end{array}$ & $\begin{array}{c}\text { It has low permeability. Slip resistance is low. The surface texture is very fine. High } \\
\text { resistance to demolition. }\end{array}$ & [92] \\
\hline $\begin{array}{l}\text { Using mineral additives } \\
\text { (natural zeolite) }\end{array}$ & $\begin{array}{l}\text { Compressive strength is increased by } 10 \% \text {. } \\
\text { It increases in density. Water absorption is reduced. }\end{array}$ & {$[1,9,93]$} \\
\hline
\end{tabular}


Table 7. Cont.

\begin{tabular}{|c|c|c|}
\hline Type of Treatment & Properties & Reference \\
\hline $\begin{array}{l}\text { Substitution of aggregate } \\
\text { for granite residues }\end{array}$ & $\begin{array}{l}\text { Optimal results are obtained by replacing } 20 \% \text { in aggregates. Decreases resistance to } \\
\text { compression, flexion and tension. } \\
\text { The density of the concrete increases. It presents an increase in water absorption, } \\
\text { abrasion and permeability. } \\
\text { The workability of concrete increases with increasing replacement of stone material. } \\
\text { It can be used in all engineering works applications. In proportions of } 20 \% \text { to } 40 \% \text {, it can } \\
\text { be used in nonstructural elements such as pavements. }\end{array}$ & [2] \\
\hline $\begin{array}{l}\text { Corrosion resistance } \\
\text { replacing cement with } \\
\text { granite powder }\end{array}$ & $\begin{array}{l}\text { Using the } 5.0 \% \text { substitution increases corrosion cracking. } \\
\text { There are no changes in the chemical properties of the mixture. } \\
\text { The optimum percentage of substitution is } 10 \% \text { for positive effects of tensile stress. }\end{array}$ & [14] \\
\hline $\begin{array}{l}\text { Mineral powders (basalt, } \\
\text { quartz, feldspar) }\end{array}$ & $\begin{array}{l}\text { There is an increase or decrease in abrasion resistance. Depending on the percentage of } \\
\text { substitution and the type of mineral. } \\
\text { The addition of } 20 \% \text { quartz increases resistance to abrasion. }\end{array}$ & [94] \\
\hline
\end{tabular}

\section{Organic Aggregates}

Studies have shown the effectiveness of fibers and organic aggregates as a complement for concrete mixtures, either to modify physical and mechanical properties of concrete or as a sustainable material in the production of this construction material. The use of these materials can reduce the consumption of natural resources, obtaining sustainable concrete.

\subsection{Bamboo}

Bamboo is a natural resource that grows in tropical zones and can reach its maximum mechanical strength in few years.

The adhesion between bamboo bars and concrete was studied by Javadian et al. [97] in cylinders with a compressive strength of $20 \mathrm{MPa}$. Bamboo bars of $10 \mathrm{~mm}$ square section were embedded in concrete cylinders and subsequently subjected to stress in a universal machine. The tensile strength and elastic modulus were measured according to the guidelines of ASTM D3039. The comparison is made between uncoated and epoxy coated with sand particles, as a result the latter showed better adhesion. On the other hand, the strength of the concrete reinforced with rice husk ash (RHA), sea shell ash (SSA) and bamboo fiber was comparable with that of normal concrete after 28 and 90 days [98]. Sikadur 32-gel can be used to improve the bonding between bamboo and concrete [99]. Agarwal et al. [100] have shown that treated bamboo reinforcement can be as good as the conventional steel reinforcement in conventional concrete.

Bamboo used as reinforcement in walls can enhance the shear capacity compared to unreinforced masonry and achieves a behavior similar to that of reinforced with steel [101] The use of bamboo as a replacement of steel reinforcement has been evaluated in beams, slabs and columns. Results provide enough strength as the members reinforced with steel. For instance, Mali and Datta [102] tested different slabs in where steel reinforcement was completely replaced by bamboo bars as indicated in Figure 10. They demonstrated that using bamboo as mainly flexural reinforcement in slab was possible had its better performance compared with the same slab containing steel reinforcement [102]. 


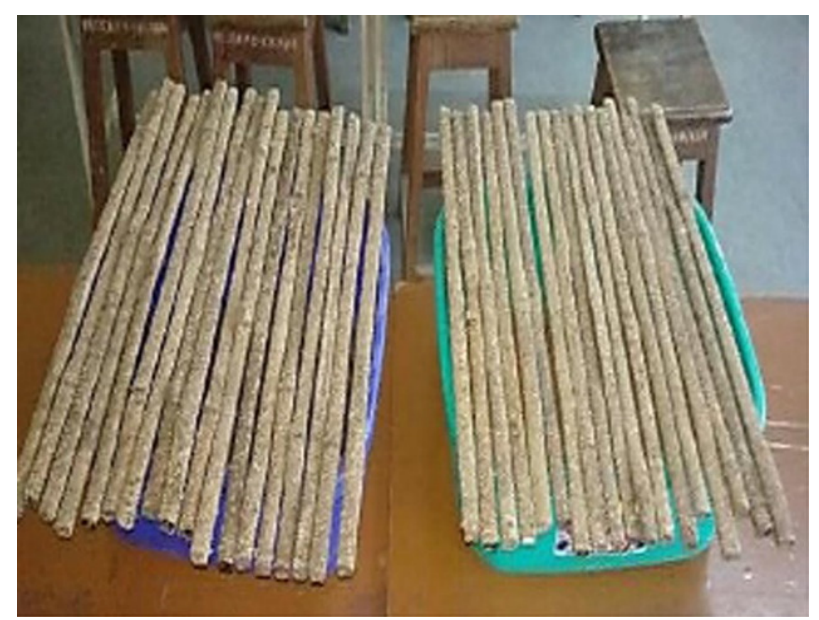

Figure 10. Bamboo reinforcement bars used in concrete slabs. Reprinted with permission from [102]. Copyright@ 2018, Elsevier B.V.

\subsection{Coconut Fiber}

Coconut fiber, extracted from the outer shell of coconuts, has great properties to be used in concrete. For instance, coconut fiber can achieve 4 to 6 times more strain in comparison with other natural fibers [103]. Moreover, coconut fiber has the highest toughness among all-natural fibers. These mechanical characteristics reduce plastic cracking, which leads to having coconut fiber concrete with enhanced flexural behavior and high impact resistance compared with traditional concrete. Nevertheless, coconut fiber concrete can reduce its compressive strength and workability [104].

Hwang et al. [104] developed experimental tests in coconut fiber concrete and observed that $4 \%$ replacement of coconut fiber in mortar can decrease its compressive strength about $50 \%$. In addition, water absorption and flexural strength of coconut fiber mortar can be increased up to $33 \%$ and $50 \%$, respectively. Based on the stress-strain curves of coconut fiber concrete, Hwang et al. [104] reported that its elastic modulus decreased while its maximum strain achieved $6 \times 10^{-3}$, which is two times more than conventional concrete [105]. Thus, coconut fiber can be used as a polymer fiber in concrete for boards, slabs and pavements [106].

Ropes composed by coconut fibers have been employed as vertical reinforcement of concrete walls to increase the structures stability against earthquakes [107]. To evaluate the tensile strength of coconut ropes, Ali and Chouw [108] developed experimental tests of coconut ropes. They proposed that the length of coconut ropes incorporated in concrete should be above $200 \mathrm{~mm}$. Additionally, they observed that coconut fiber concrete and boiled treatment of ropes increase their bond strength and pullout energy [108]. Regarding the performance of coconut fiber and rope reinforced concrete columns tested on shaking tables, Ali [109] verified that nonvisible degradation occurred prior to the cracking these columns. Furthermore, one rope configuration could maintain the column attached to its support after being tested. On the other hand, Wang and Chouw [110] used coconut fibers (see Figure 11) to improve concrete properties under load impact. They determined that coconut fiber reduced spalling and cracking of coconut fiber concrete. Finally, to determine the complete behavior of coconut fiber and ropes in concrete, it is recommended to carry out experimental tests about the ductility and microstructure of columns and beams containing coconut fibers. 


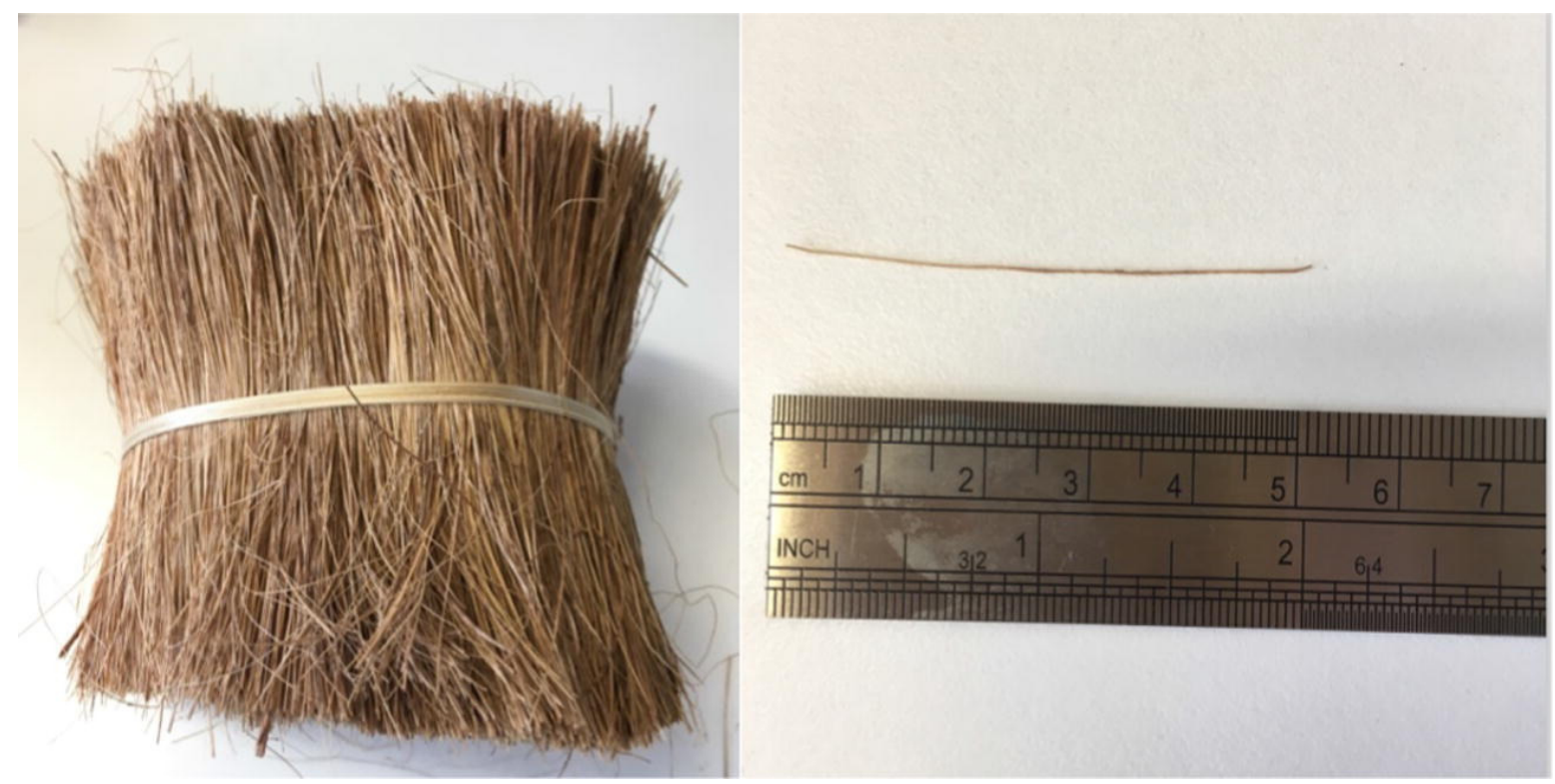

Figure 11. Coconut fibers used to improve concrete properties. Reprinted with permission from [110]. Copyright@ 2017, Elsevier B.V.

\subsection{Nanocellulose}

Nanocellulose can be aggregated in concrete to improve its mechanical properties and durability [111]. Nanocellulose is the most abundant renewable polymer that could be used in the construction industry [112]. There are different types of structures such as bacterial cellulose, nanofibers and isolated nanocrystals [113]. Nanocellulose has important properties such as low cost, light weight, low health hazard, biocompatibility, low toxicity and low production costs of natural resources $[114,115]$.

Wu et al. [116] studied the mechanical strength of microfilaments based in bacterial cellulose and regenerated bacterial cellulose, obtaining important breakthroughs in the development of various materials [116]. These bacterial celluloses have been employed to prevent microbial corrosion of concrete [117]. Furthermore, Aitomaki and Oksman [113] investigated the efficiency of nanocellulose as reinforcement employed as polymer, considering the properties of elastic modulus and strength. Nanocellulose can be obtained through plants, microbes, natural chemical reactions and enzymatic synthesis. On the other hand, Islam et al. [118] presented information about production and cost-efficiency relation strategies of bacterial cellulose.

The use of nanofibers as a reinforcement material in concrete can improve the concrete service life and mechanical strength. Cengiz et al. [119] made concrete mixtures using nanofibers obtained from waste algae (Cladophora $s p$ ) and commercial cotton cellulose nanofibers. Both types of nanofibers were added in cement mixtures. For concrete specimens incorporated with $1.0 \mathrm{~g}$ cellulose nanofiber (generated from waste algae), the flexural strength of the specimens increased up to $5.96 \mathrm{MPa}$, which is $3.74 \mathrm{MPa}$ higher than that control concrete specimen (without nanofibers). However, the concrete specimens added commercial cellulose nanofiber showed a reduction of their flexural strength compared with control specimen. These algal cellulose nanofibers are abundant in nature and can be used as reinforced materials in concrete.

Lee et al. [120] presented a review about various types of nanocellulose polymers that have potential application as reinforcement in concretes and tensile strength. De Koster et al. [121] developed a methodology for the self-repair of concrete with structural failures through a bacteria that produces calcium carbonate. This bacteria is mixed with concrete in an encapsulated form with a geopolymer (on account of the reaction of the bacteria with water). Thus, when the first crack is generated, there will be a water flow that breaks the capsule, and the bacteria kicks off the self-repairing process. Based on the strength results 
of geopolymer cubes $(20 \mathrm{~mm} \times 20 \mathrm{~mm} \times 25 \mathrm{~mm}$ ), average strength of $26.89 \mathrm{MPa}$ and $28.04 \mathrm{MPa}$ were measured after one and four weeks of curing, respectively.

The use of nanocellulose to enhance the concrete performance leads to sustainable and environmentally friendly products. In addition, nanocellulose can have future applications as self-repairing material to solve structural problems in buildings (see Figure 12) [122]. Table 8 shows significant information on the improvement of concrete using organic aggregates, coconut fiber, bamboo and nanocellulose.

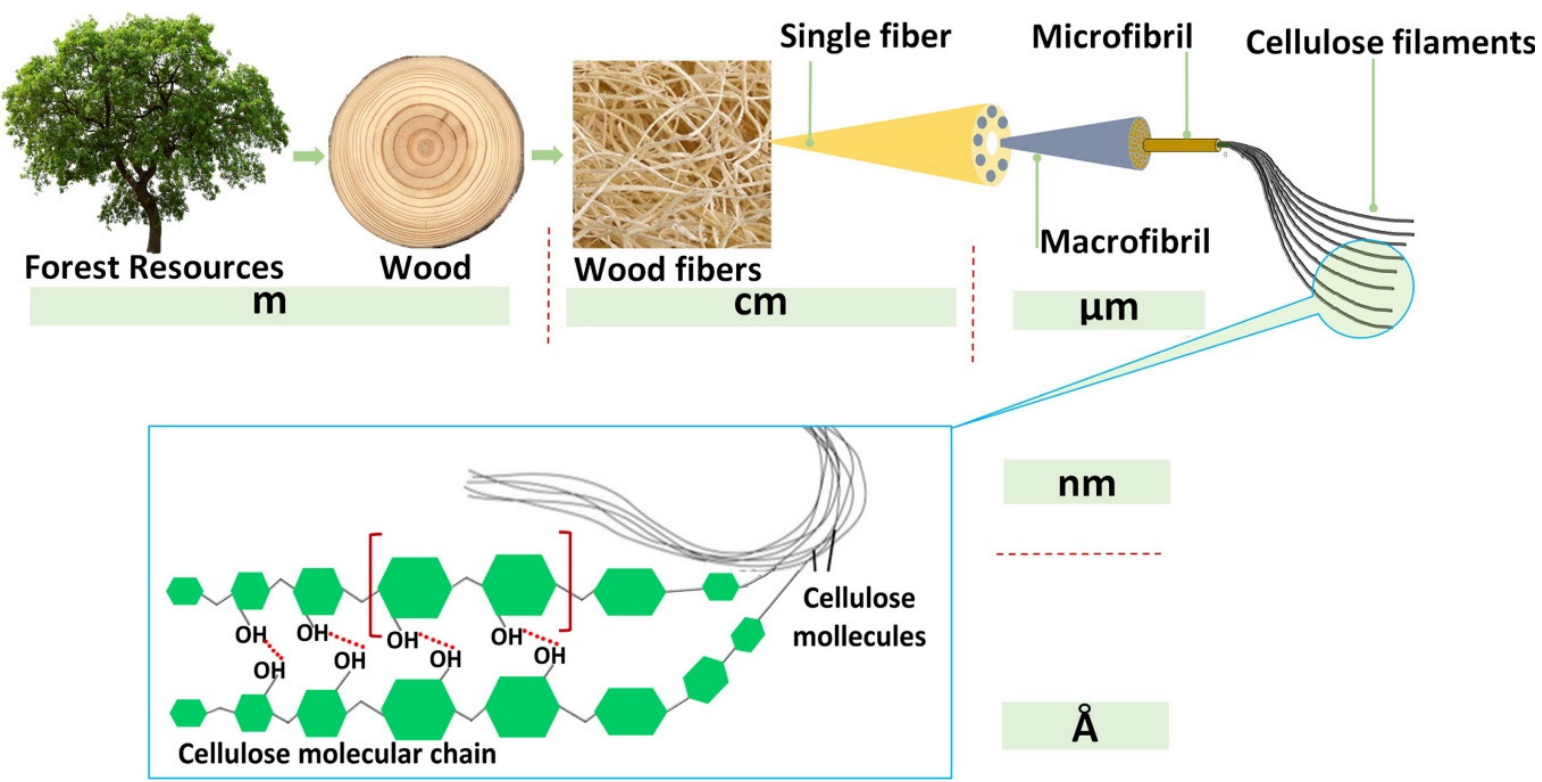

Figure 12. Scheme of procedure to obtain nanocelluse used for improving concrete properties. Reprinted with permission from [122]. Copyright@ 2019, Elsevier B.V.

Table 8. Summary of some treatments with the most significant properties of organic aggregates.

\begin{tabular}{|c|c|c|}
\hline Type of Treatment & Properties & Reference \\
\hline $\begin{array}{l}\text { Efficiency } \\
\text { of concrete with bamboo fiber }\end{array}$ & $\begin{array}{l}\text { The concrete added with bamboo fiber to reinforce the concrete and the mixture of } \\
\text { rice hull ash and sea shell ash was added. } \\
\text { Tensile strength is comparable to conventional concrete. }\end{array}$ & [97] \\
\hline Bamboo fiber & $\begin{array}{l}\text { It is a sustainable material to be used in the construction sector. } \\
\text { This material is used in structural elements as beams, slabs and columns. }\end{array}$ & [99] \\
\hline $\begin{array}{l}\text { Bamboo reinforcing } \\
\text { masonry walls }\end{array}$ & $\begin{array}{l}\text { Viable alternative to be applied in low-cost housing where bamboo is more } \\
\text { profitable than steel. }\end{array}$ & [100] \\
\hline $\begin{array}{l}\text { Bamboo reinforced } \\
\text { concrete slabs }\end{array}$ & $\begin{array}{l}\text { Bamboo is analyzed as a sustainable, removable and ecological material that aims } \\
\text { to replace steel. } \\
\text { Pull-out tests were performed to test efficacy. } \\
\text { There is a significant improvement in flex performance. }\end{array}$ & [102] \\
\hline $\begin{array}{l}\text { Coconut fiber reinforced } \\
\text { concrete }\end{array}$ & $\begin{array}{l}\text { The results of the deflection and the width of the crack are comparable for } \\
\text { conventional concretes. }\end{array}$ & [105] \\
\hline Coconut fiber analysis & $\begin{array}{l}\text { The morphology and the physical and mechanical properties of the coconut fibers } \\
\text { were analyzed. The area of the coconut fibers was studied using SEM images. The } \\
\text { densities of the fibers decreased as the diameters increased. }\end{array}$ & [106] \\
\hline $\begin{array}{l}\text { Behavior of coconut fiber } \\
\text { reinforced concrete under } \\
\text { impact load }\end{array}$ & $\begin{array}{l}\text { Coconut fiber reinforced concrete was tested using cyclical impact loads. Based on } \\
\text { the results obtained, an empirically derived equation was proposed. }\end{array}$ & [110] \\
\hline $\begin{array}{l}\text { Cellulose nanofibers from } \\
\text { algae waste }\end{array}$ & Increases flexural strength of concrete. & [119] \\
\hline
\end{tabular}




\section{Recommendations}

Most researchers do not use guidelines of standards to obtain sustainable concrete specimens that will be used in compressive strength tests and other standardized tests. For instance, the follows guidelines of standards could be employed: ASTM C1074-11 "Standard Practice for Estimating Concrete Strength by the Maturity Method" and ASTM C39/C39-17B Standard Test Method for Compressive Strength of Cylindrical Concrete Specimens among others well stablished codes. The use of standardized tests is recommended to ensure reliable results of the effect of the sustainable materials on the physical and mechanical properties of the concrete specimens. Thus, these results could be compared to identify the optimal content and type of sustainable material added in concrete that generates the best concrete performance. Civil engineers could choose the best sustainable concrete for each construction with specific requirements.

Recycled materials incorporated in concrete show a high absorption capacity that cause workability problems in fresh concrete affecting its mechanical strength. Therefore, it is advisable to find the optimal combination of materials from different origins to improve these properties of the sustainable concrete.

\section{Conclusions}

Recycled alternative materials used as aggregates or cementing agents in concrete can improve the physical and mechanical properties of sustainable concrete using optimal dosages of these materials. In addition, the use of these recycled materials can help to decrease $\mathrm{CO}_{2}$ emissions and to save natural resources. Sustainable materials as ceramic waste used as aggregate in concrete can enhance the mechanical properties of the concrete.

Potential applications of sustainable concrete added with organic materials or industrial waste are nonstructural elements such as sidewalks, partition walls, road barriers, pavements, boards, slabs, curbs and sport fields. However, the use of recycled materials or industrial waste added in concrete requires more investigations about the impact of these materials on the concrete performance. Thus, optimal content of these materials could be incorporated in concrete to obtain the best mechanical behavior of the sustainable concrete.

Author Contributions: S.A.Z.-C., R.S.-E., L.C.S.-H., R.A.M.-A., E.M.-H., E.Y.-C. and A.L.H.-M. wrote, coordinated, reviewed and contributed to scientific aspects the article. All authors have read and agreed to the published version of the manuscript.

Funding: This research received no external funding.

Institutional Review Board Statement: Not applicable.

Informed Consent Statement: Not applicable.

Data Availability Statement: Request the corresponding author of this article.

Acknowledgments: Thanks to COVEICYDET (Veracruz Council for Scientific Research and Technological) for the support and facilities for the publication of this article.

Conflicts of Interest: The authors declare no conflict of interest.

\section{References}

1. Nagrockienè, D.; Girskas, G.; Skripkiūnas, G. Properties of concrete modified with mineral additives. Constr. Build. Mater. 2017, 135, 37-42. [CrossRef]

2. Sharma, N.K.; Kumar, P.; Kumar, S.; Thomas, B.S.; Gupta, R.C. Properties of concrete containing polished granite waste as partial substitution of coarse aggregate. Constr. Build. Mater. 2017, 151, 158-163. [CrossRef]

3. Yang, S.T.; Li, K.F.; Li, C.Q. Numerical determination of concrete crack width for corrosion-affected concrete structures. Comput. Struct. 2018, 207, 75-82. [CrossRef]

4. McGinnis, M.J.; Davis, M.; de la Rosa, A.; Weldon, B.D.; Kurama, Y.C. Strength and stiffness of concrete with recycled concrete aggregates. Constr. Build. Mater. 2017, 154, 258-269. [CrossRef]

5. Tiwari, A.; Singh, S.; Nagar, R. Feasibility assessment for partial replacement of fine aggregate to attain cleaner production perspective in concrete: A review. J. Clean. Prod. 2016, 135, 490-507. [CrossRef] 
6. Rashid, K.; Razzaq, A.; Ahmad, M.; Rashid, T.; Tariq, S. Experimental and analytical selection of sustainable recycled concrete with ceramic waste aggregate. Constr. Build. Mater. 2017, 154, 829-840. [CrossRef]

7. Kubissa, W.; Jaskulski, R.; Reiterman, P.; Supera, M. Ecological high performance concrete. Procedia Eng. 2017, 172, 595-603. [CrossRef]

8. Torres, A.; Bartlett, L.; Pilgrim, C. Effect of foundry waste on the mechanical properties of Portland Cement Concrete. Constr. Build. Mater. 2017, 135, 674-681. [CrossRef]

9. Markiv, T.; Sobol, K.; Franus, M.; Franus, W. Mechanical and durability properties of concretes incorporating natural zeolite. Arch. Civil. Mech. Eng. 2016, 16, 554-562. [CrossRef]

10. Prusty, J.K.; Patro, S.K.; Basarkar, S.S. Concrete using agro-waste as fine aggregate for sustainable built environment-A review. Int. J. Sustain. Built Environ. 2016, 5, 312-333. [CrossRef]

11. Matar, W.; Elshurafa, A.M. Striking a balance between profit and carbon dioxide emissions in theSaudi cement industry. Int. J. Greenh. Gas Control 2017, 61, 111-123. [CrossRef]

12. Parthiban, K.; Mohan, K.S.R. Influence of recycled concrete aggregates on the engineering and durability properties of alkali activated slag concrete. Constr. Build. Mater. 2017, 133, 65-72. [CrossRef]

13. Fan, X.; Zhang, M. Behaviour of inorganic polymer concrete columns reinforced with basalt FRP bars under eccentric compression: An experimental study. Compos. Part B 2016, 104, 44-56. [CrossRef]

14. Elmoaty, A.E.M.A. Mechanical properties and corrosion resistance of concrete modified with granite dust. Constr. Build. Mater. 2013, 47, 743-752. [CrossRef]

15. Popek, M.; Sadowskia, L. Selected physical properties of concrete modified using mineral Powders. Procedia Eng. 2017, 172, 891-896. [CrossRef]

16. Maier, P.L.; Durham, S. Beneficial use of recycled materials in concrete mixtures. Constr. Build. Mater. 2012, 29, 428-437. [CrossRef]

17. Gholampour, A.; Ozbakkaloglu, T. Performance of sustainable concretes containing very high volume Class-F fly ash and ground granulated blast furnace slag. J. Clean. Prod. 2017, 162, 1407-1417. [CrossRef]

18. Bulut, H.A.; Sahin, R. A study on mechanical properties of polymer concrete containing electronic plastic waste. Compos. Struct. 2017, 178, 50-62. [CrossRef]

19. Fallah, S.; Nematzadeh, M. Mechanical properties and durability of high-strength concrete containing macro-polymeric and polypropylene fibers with nano-silica and silica fume. Constr. Build. Mater. 2017, 132, 170-187. [CrossRef]

20. Torring, M.; Ravindra, E.L.; Dyer, T.D.; Halliday, J. Total recycling opportunities-Tasting the topics for the conference session. In Challenges of Concrete Construction: Sustainable Concrete Construction Pt. 1, v. 5: Proceedings of the International Conference Held at the University of Dundee, Scotland, UK, 9-11 September 2002; Halliday, J.E., Ed.; ICE Publishing: London, UK, 2002 ; pp. 501-510. [CrossRef]

21. Mohammed, T.U.; Hasnat, A.; Awal, M.A.; Bosuni, S.Z. Recycling of brick aggregate concrete as coarse aggregate. J. Mater. Civ. Eng. 2015, 27, B401005. [CrossRef]

22. Richarson, A.; Covertry, K.; Bacon, J. Freeze/thaw durability of concrete with recycled demolition aggregate compared to virgin aggregate concrete. J. Clean. Prod. 2011, 19, 272-277. [CrossRef]

23. Šeps, K.; Fládr, J.; Broukalová, I. Resistance of recycled aggregate concrete to freeze-thaw and deicing salts. Procedia Eng. 2016, 151, 329-336. [CrossRef]

24. Gao, C.; Huang, L.; Yan, L.; Kasal, B.; Li, W. Behavior of glass and carbon FRP tube encased recycled aggregate concrete with recycled clay brick aggregate. Compos. Struct. 2016, 155, 245-254. [CrossRef]

25. Yang, J.; Du, Q.; Bao, Y. Concrete with recycled aggregate and crushed clay bricks. Constr. Build. Mater. 2011, $25,1935-1945$. [CrossRef]

26. Baena, M.; Torre, L.; Turon, A.; Llorens, M.; Barris, C. Bond behaviour between recycled aggregate concrete and glass fibre reinforced polymer bars. Constr. Build. Mater. 2016, 106, 449-460. [CrossRef]

27. Seara-Paz, S.; González-Fonteboa, B.; Martínez-Abella, F.; González-Taboada, I. Time-dependent behaviour of structural concrete made with recycled coarse aggregates. Creep and shrinkage. Constr. Build. Mater. 2016, 122, 95-109. [CrossRef]

28. Guo, S.; Dai, Q.; Si, R.; Sun, X.; Lu, C. Evaluation of properties and performance of rubber-modified concrete for recycling of waste scrap tire. J. Clean. Prod. 2017, 148, 681-689. [CrossRef]

29. Siddique, R.; Naik, T.R. Properties of concrete containing scrap-tire rubber-An overview. Waste Manag. 2014, 6, 563-569. [CrossRef]

30. Liu, L.; Cai, G.; Zhang, J.; Liu, X.; Liu, K. Evaluation of engineering effect of recycled waste tire-sand/soil in geotechnical engineering: A compressive review. Renew. Sustain. Energy Rev. 2020, 126, 109831. [CrossRef]

31. Mohajerani, A.; Burnett, L.; Smith, J.V.; Markovski, S.; Rodwell, G.; Rahman, M.T.; Kurmus, H.; Mirzababaei, M.; Arulrajah, A.; Horpibulsuk, S.; et al. Rcycling waste rubber tyres in construction materials and associated environmental considerations: A review. Resour. Conserv. Recycl. 2020, 155, 104679. [CrossRef]

32. Asutkar, P.; Shinde, S.B.; Patel, R. Study on the behaviour of rubber aggregates concrete beams using analytical approach. Eng. Sci. Technol. Int. J. 2017, 20, 151-159. [CrossRef]

33. Thomas, B.S.; Gupta, R.C. Properties of high strength concrete containing scrap tire rubber. J. Clean. Prod. 2016, 113, 86-92. [CrossRef] 
34. Medina, N.F.; Medina, D.F.; Hernández-Olivares, F.; Navacerrada, M.A. Mechanical and thermal properties of concrete incorporating rubber and fibres from tyre recycling. Constr. Build. Mater. 2017, 144, 563-573. [CrossRef]

35. Thomas, B.S.; Gupta, R.C. A comprehensive review on the applications of waste tire rubber in cement concrete. Renew. Sustain. Energy Rev. 2016, 54, 1323-1333. [CrossRef]

36. Bompa, D.V.; Elghazouli, A.Y. Creep properties of recycled tyre rubber concrete. Constr. Build. Mater. 2019, 209, 126-134. [CrossRef]

37. Law, K.L.; Starr, N.; Siegler, T.R.; Jambeck, J.R.; Mallos, N.J.; Leonard, G.H. The United States' contribution of plastic waste to land and ocean. Sci. Adv. 2020, 6, eabd0288. [CrossRef]

38. Dalhat, M.A.; Wahhab, H.I.A.-A. Cement-less and asphalt-less concrete bounded by recycled plastic. Constr. Build. Mater. 2016, 119, 206-214. [CrossRef]

39. Choi, Y.-W.; Moon, D.-J.; Chung, J.-S.; Cho, S.-K. Effects of waste PET bottles aggregate on the properties of concrete. Cem. Concr. Res. 2005, 35, 776-781. [CrossRef]

40. Islam, M.J.; Meherier, M.S.; Islam, A.K.M.R. Effects of waste PET as coarse aggregate on the fresh and harden properties of concrete. Constr. Build. Mater. 2016, 125, 946-951. [CrossRef]

41. Lucano, F.; Liguori, B.; Caputo, D.; Colangelo, F.; Coiffi, R. Recycled plastic aggregate in mortars composition: Effect of physical and mechanical properties. Mater. Des. 2013, 52, 916-922. [CrossRef]

42. Mohammed, A.A. Modelling the mechanical properties of concrete containing PET waste aggregate. Constr. Build. Mater. 2017, 150, 595-605. [CrossRef]

43. Bui, N.C.; Satomi, T.; Takahashi, H. Recycling woven plastic sack waste and PET bottle waste as fiber in recycled aggregate concrete: An experimental study. Waste Manag. 2018, 78, 79-93. [CrossRef] [PubMed]

44. Žlebek, T.; Hodul, J.; Drochytka, R. Experimental Testing Suitability of the Waste Glass into the Polymer Anchor Materials Based on Epoxy Resin. Procedia Eng. 2017, 195, 220-227. [CrossRef]

45. Cota, F.P.; Melo, C.C.D.; Panzera, T.H.; Araújo, A.G.; Borges, P.H.R.; Scarpa, F. Mechanical properties and ASR evaluation of concrete tiles with waste glass aggregate. Sustain. Cities Soc. 2015, 16, 49-56. [CrossRef]

46. Rashad, A.M. Recycled waste glass as fine aggregate replacement in cementitious materials based on Portland cement. Constr. Build. Mater. 2014, 72, 340-357. [CrossRef]

47. De Castro, S.; De Brito, J. Evaluation of the durability of concrete made with crushed glass aggregates. J. Clean. Prod. 2013, 41, 7-14. [CrossRef]

48. ASTM. Standard Test Method for Static Segregation of Self Consolidating Concrete Using Column Technique; ASTM C1610; ASTM International: West Conshohocken, PA, USA, 2019.

49. Ali, E.E.; Al-Tersawy, S.H. Recycled glass as a partial replacement for fine aggregate in self compacting concrete. Constr. Build. Mater. 2012, 35, 785-791. [CrossRef]

50. Cassar, J.; Camilleri, J. Utilisation of imploded glass in structural concrete. Constr. Build. Mater. 2012, 29, 299-307. [CrossRef]

51. Saribiyik, M.; Piskin, A.; Saribiyik, A. The effects of waste glass powder usage on polymer concrete properties. Constr. Build. Mater. 2013, 47, 840-844. [CrossRef]

52. Afshinnia, K.; Rangaraju, P.R. Impact of combined use of ground glass powder and crushed glass aggregate on selected properties of Portland cement concrete. Constr. Build. Mater. 2016, 117, 263-272. [CrossRef]

53. Soliman, N.A.; Tagnit-Hamou, A. Development of ultra-high-performance concrete using glass powder-Towards ecofriendly concrete. Constr. Build. Mater. 2016, 125, 600-612. [CrossRef]

54. Lee, G.; Poon, C.S.; Wong, Y.L.; Ling, T.C. Effects of recycled fine glass aggregates on the properties of dry-mixed concrete blocks. Constr. Build. Mater. 2013, 38, 638-643. [CrossRef]

55. Chidiac, S.E.; Mihaljevic, S.N. Performance of dry cast concrete blocks containing waste glass powder or polyethylene aggregates. Cem. Concr. Compos. 2011, 33, 855-863. [CrossRef]

56. de Rosso, L.C.; de Melo, J.V.S. Impact of incorporing recycled glass on the photocatalytic capacity of paving concrete blocks. Constr. Build. Mater. 2020, 259, 119778. [CrossRef]

57. Bostanci, S.C. Use of waste marble dust and recycled glass for sustainable concrete production. J. Clean. Prod. 2020, 251, 119785. [CrossRef]

58. Dash, M.K.; Patro, S.K.; Rath, A.K. Sustainable use of industrial-waste as partial replacement of fine aggregate for preparation of concrete-A review. Int. J. Sustain. Built Environ. 2016, 5, 484-516. [CrossRef]

59. De Almeida-Lima, D.; Zulanas, C. Use of Contaminated Sludge in Concrete. Procedia Eng. 2016, 45, 1201-1208. [CrossRef]

60. Lee, T.-C.; Lin, K.-L.; Su, X.-W.; Lin, K.-K. Recycling CMP sludge as a resource in concrete. Constr. Build. Mater. 2012, 30, $243-251$. [CrossRef]

61. Sharmila, P.; Dhinakaran, G. Compressive strength, porosity and sorptivity of ultra fine slag based high strength concrete. Constr. Build. Mater. 2016, 120, 48-53. [CrossRef]

62. Xu, B.W.; Shi, H.S. Correlations among mechanical properties of steel fibre reinforced concrete. Constr. Build. Mater. 2009, 23, 3468-3474. [CrossRef]

63. Biskri, Y.; Achoura, D.; Chelghoum, N.; Mouret, M. Mechanical and durability characteristics of High Performance Concrete containing steel slag and crystalized slag as aggregates. Constr. Build. Mater. 2017, 150, 167-178. [CrossRef] 
64. Sengul, O. Mechanical behavior of concretes containing waste steel fibers recovered from scrap tires. Constr. Build. Mater. 2016, 122, 649-658. [CrossRef]

65. Yu, X.; Tao, Z.; Song, T.-Y.; Pan, Z. Performance of concrete made with steel slag and waste glass. Constr. Build. Mater. 2016, 114, 737-746. [CrossRef]

66. Pogorelov, S.N.; Semenyak, G.S. Frost Resistance of the Steel Fiber Reinforced Concrete Containing Active Mineral Additives. Procedia Eng. 2016, 150, 1491-1495. [CrossRef]

67. Roslan, N.H.; Ismail, M.; Abdul-Majid, Z.; Ghoreishiamiri, S.; Muhammad, B. Performace of steel slag and steel sludge in concrete. Constr. Build. Mater. 2016, 104, 16-24. [CrossRef]

68. Choun, Y.-S.; Park, H.-K. Containment performance evaluation of prestressed concrete containment vessels with fiber reinforcement. Nucl. Eng. Technol. 2015, 47, 884-894. [CrossRef]

69. Carrillo, J.; Aperador, W.; González, G. Correlations between Mechanical Properties of Steel Fiber Reinforced Concrete. Ing. Investig. Tecnol. 2013, 14, 435-450. Available online: https://www.sciencedirect.com/science/article/pii/S140577431372256X (accessed on 25 October 2020).

70. Chaboki, H.R.; Ghalehnovi, M.; Karimipour, A.; de Brito, J.; Khatibinia, M. Shear behaviour of concrete beams with recycled aggregate and steel fibres. Constr. Build. Mater. 2019, 204, 809-827. [CrossRef]

71. Ali, B.; Qureshi, L.A.; Shah, S.H.A.; Rehman, S.U.; Hussain, I.; Iqbal, M. A step towards durable, ductile and sustainable concrete: Simultanueous, incorporation of recycled aggregates, glass fiber and fly ash. Constr. Build. Mater. 2020, 251, 118980. [CrossRef]

72. Moghadam, M.A.; Izadifard, R.A. Effects of steel and glass fibers on mechanical and durability properties of concrete exposed to high temperatures. Fire Saf. J. 2020, 113, 102978. [CrossRef]

73. Mastali, M.; Dalvand, A.; Sattarifard, A.R. The impact resistance and mechanical properties of reinforced self- compacting concrete with recycled glass fibre reinforced polymers. J. Clean. Prod. 2016, 124, 312-324. [CrossRef]

74. Khan, M.; Ali, M. Use of glass and nylon fibers in concrete for controlling early age micro cracking in bridge decks. Constr. Build. Mater. 2016, 125, 800-808. [CrossRef]

75. Jarek, B.; Kubik, A. The examination of the glass fiber reinforced polymer composite rods in terms of the application for concrete reinforcement. Procedia Eng. 2015, 108, 394-401. [CrossRef]

76. Rezazadehm, N. Innovative Methodologies for the Enhancement of the Flexural Strengthening Performance of NSM CFRP Technique for RC Beams. Ph.D. Dissertation, University of Minho, Azurém, Guimarães, Portugal, 2015.

77. Camata, G.; Spacone, E.; Zarnic, R. Experimental and nonlinear finite element studies of RC beams strengthened with FRP plates. Compos. Part B Eng. 2007, 38, 277-288. [CrossRef]

78. Tahsiri, H.; Sedehi, O.; Khaloo, A.; Raisi, E.M. Experimental study of RC jacketed and CFRP strengthened RC beams. Constr. Build. Mater. 2015, 95, 476-485. [CrossRef]

79. Cheng, D.; Yang, Y. Design method for concrete columns strengthened with prestressed CFRP sheets. Constr. Build. Mater. 2017, 151, 331-344. [CrossRef]

80. Rodrigues, H.; Furtado, A.; Arêde, A. Experimental evaluation of energy dissipation and viscous damping of repaired and strengthened RC columns with CFRP jacketing under biaxial load. Eng. Struct. 2017, 145, 162-175. [CrossRef]

81. Wang, D.; Wang, Z.; Smith, S.T.; Yu, T. Seismic performance of CFRP-confined circular high-strength concrete columns with high axial compression ratio. Constr. Build. Mater. 2017, 134, 91-103. [CrossRef]

82. Kong, K.; Mesticou, Z.; Michel, M.; Larbi, A.S.; Junes, A. Comparative characterization of the durability behaviour of textilereinforced concrete (TRC) under tension and bending. Compos. Struct. 2017, 179, 107-123. [CrossRef]

83. D'Antino, T.; Papanicolaou, C. Mechanical characterization of textile reinforced inorganic-matrix composites. Compos. Part B Eng. 2017, 127, 78-91. [CrossRef]

84. De Santis, S.; Carozzi, F.G.; de Felice, G.; Poggi, C. Test methods for textile reinforced mortar systems. Compos. Part B Eng. 2017, 127, 121-132. [CrossRef]

85. Valeri, P.; Guaita, P.; Baur, R.; Ruiz, M.F.; Fernández-Ordónez, D.; Muttoni, A. Textile reinforced concrete for sustainable structures: Future perspectives and application to a prototype pavilion. Struct. Concr. 2020, 1-17. [CrossRef]

86. Jing, L.; Yin, S.; Aslani, F. Experimental investigation on compressive performance of masonry columns confined with textilereinforced concrete. Constr. Build. Mater. 2020, 269, 121270. [CrossRef]

87. Peña-Pichardo, P.; Martínez-Barrera, G.; Martínez-López, M.; Ureña-Núñez, F.; dos Reis, J.M.L. Recovery of cotton fibers from waste Blue-Jeans and its use in polyester concrete. Constr. Build. Mater. 2018, 177, 409-416. [CrossRef]

88. Anagnostopoulos, C.A.; Sapidis, G.; Papastergiadis, E. Fundamental properties of epoxy resin-modified cement grouts. Constr. Build. Mater. 2016, 125, 184-195. [CrossRef]

89. Ariffin, N.F.; Hussin, M.W.; Sam, A.R.M.; Bhutta, M.A.R.; Khalid, N.H.A.; Mirza, J. Strength properties and molecular composition of epoxy-modified mortars. Constr. Build. Mater. 2015, 94, 315-322. [CrossRef]

90. Ferdous, W.; Manalo, A.; Aravinthan, T.; Erp, G.V. Properties of epoxy polymer concrete matrix: Effect of resin-to-filler ratio and determination of optimal mix for composite railway sleepers. Constr. Build. Mater. 2016, 124, 287-300. [CrossRef]

91. Toufigh, V.; Hosseinali, M.; Shirkhorshidi, S.M. Experimental study and constitutive modeling of polymer concrete's behavior in compression. Constr. Build. Mater. 2016, 112, 183-190. [CrossRef]

92. Zhong, K.; Yang, X.; Wei, X. Investigation on surface characteristics of epoxy asphalt concrete pavement. Int. J. Pavement Res. Technol. 2017, 10, 545-552. [CrossRef] 
93. Nagrockienè, D.; Girskas, G. Research into the properties of concrete modified with natural zeolite addition. Constr. Build. Mater. 2016, 113, 964-969. [CrossRef]

94. Popek, M.; Sadowski, L.; Szymanowski, J. Abrasion resistance of concrete containing selected mineral powders. Procedia Eng. 2016, 153, 617-622. [CrossRef]

95. Atutis, E.; Valivonis, J.; Atutis, M. Experimental study of concrete beams prestressed with basalt fiber reinforced polymers under cyclic load. Compos. Struct. 2018, 183, 389-396. [CrossRef]

96. Sardinha, M.; de Brito, J.; Rodrigues, R. Durability properties of structural concrete containing very fine aggregates of marble sludge. Constr. Build. Mater. 2016, 119, 45-52. [CrossRef]

97. Javadian, A.; Wielopolski, M.; Smith, I.F.; Hebel, D.E. Bond-behavior study of newly developed bamboo-composite reinforcement in concrete. Constr. Build. Mater. 2016, 122, 110-117. [CrossRef]

98. Wahyuni, A.S.; Supriani, F.; Elhusna; Gunawan, A. The performance of concrete with rice husk ash sea Shell ash and bamboo fibre addition. Procedia Eng. 2014, 95, 473-478. [CrossRef]

99. Ghavami, K. Bamboo as reinforcement in structural concrete elements. Cem. Concr. Compos. 2005, 27, 637-649. [CrossRef]

100. Agarwal, A.; Nanda, B.; Maity, D. Experimental investigation on the chemically treated bamboo reinforced concrete beams and columns. Constr. Build. Mater. 2014, 71, 610-617. [CrossRef]

101. Moroz, J.G.; Lissel, S.L.; Hagel, M.D. Performance of bamboo reinforced concrete masonry shear walls. Constr. Build. Mater. 2014, 61, 125-137. [CrossRef]

102. Mali, P.R.; Datta, D. Experimental evaluation of bamboo reinforced concrete slab panels. Constr. Build. Mater. 2018, 188, 1092-1100. [CrossRef]

103. Munawar, S.S.; Umemura, K.; Kawai, S. Characterization of the morphological, physical, and mechanical properties of seven nonwood plant fiber bundles. J. Wood Sci. 2007, 53, 108-113. [CrossRef]

104. Hwang, C.-L.; Tran, V.-A.; Hong, J.-W.; Hiseh, Y.-C. Effects of short coconut fiber on the mechanical properties, plastic cracking behavior, and impact resistance of cementitious composites. Constr. Build. Mater. 2016, 127, 984-992. [CrossRef]

105. Jayaprithika, A.; Sekar, S.K. Stress-strain characteristics and flexural behaviour of reinforced Eco-friendly coconut shell concrete. Constr. Build. Mater. 2016, 117, 244-250. [CrossRef]

106. Lertwattanaruk, P.; Suntijitto, A. Properties of natural fiber cement materials containing coconut coir and oil palm fibers for residential building applications. Constr. Build. Mater. 2015, 94, 664-669. [CrossRef]

107. Ali, M.; Gultom, R.J.; Chouw, N. Capacity of innovative interlocking blocks under monotonic loading. Constr. Build. Mater. 2012, 37, 812-821. [CrossRef]

108. Ali, M.; Chouw, N. Experimental investigations on coconut-fibre rope tensile strength and pullout from coconut fibre reinforced concrete. Constr. Build. Mater. 2013, 41, 681-690. [CrossRef]

109. Ali, M. Seismic performance of coconut-fibre-reinforced-concrete columns with different reinforcement configurations of coconutfibre ropes. Constr. Build. Mater. 2014, 70, 226-230. [CrossRef]

110. Wang, W.; Chouw, N. The behaviour of coconut fibre reinforced concrete (CFRC) under impact loading. Constr. Build. Mater. 2017, 134, 452-461. [CrossRef]

111. Parveen, S.; Rana, S.; Fangueiro, R. Macro and nanodimensional plant fiber reinforcements for cementitious composites. In Sustainable and Nonconvencional Construction Materials Using Inorganic Bonded Fiber Composites; Woodhead Publishing: Sawston, UK, 2017; Volume 10, pp. 343-382. [CrossRef]

112. Salas, C.; Nypelö, T.; Rodriguez-Abreu, C.; Carrillo, C.; Rojas, O.J. Nanocellulose properties and applications in colloids and interfaces. Curr. Opin. Colloid Interface Sci. 2014, 19, 383-396. [CrossRef]

113. Aitomäki, Y.; Oksman, K. Reinforcing efficiency of nanocellulose in polymers. React. Funct. Polym. 2014, 85, 151-156. [CrossRef]

114. Ruiz-Palomero, C.; Soriano, M.L.; Valcárcel, M. Nanocellulose as analyte and analytical tool: Opportunities and Challenges. Trends Anal. Chem. 2017, 87, 1-18. [CrossRef]

115. Tardy, B.L.; Yokota, S.; Ago, M.; Xiang, W.; Kondo, T.; Bordes, R.; Rojas, O.J. Nanocellulose-surfactant interactions. Curr. Opin. Colloid Interface Sci. 2017, 29, 57-67. [CrossRef]

116. Wu, H.-L.; Bremner, D.H.; Wang, H.; Wu, J.-Z.; Li, H.-Y.; Wu, J.; Niu, S.-W.; Zhu, L.-M. Fabrication and investigation of a biocompatible microfilament with high mechanical performance based on regenerated bacterial cellulose and bacterial cellulose. Mater. Sci. Eng. C 2017, 79, 516-524. [CrossRef]

117. Kong, L.; Zhang, B.; Fang, J. Study on the applicability of bactericides to prevent concrete microbial corrosión. Constr. Build. Mater. 2017, 149, 1-8. [CrossRef]

118. Islam, M.U.; Ullah, M.W.; Khan, S.; Shah, N.; Park, J.K. Strategies for cost-effective and enhanced production of bacterial cellulose. Int. J. Biol. Macromol. 2017, 102, 1166-1173. [CrossRef] [PubMed]

119. Cengiz, A.; Kaya, M.; Bayramgil, N.P. Flexural stress enhancement of concrete by incorporation of algal cellulose nanofibers. Constr. Build. Mater. 2017, 149, 289-295. [CrossRef]

120. Lee, K.-Y.; Aitomäki, Y.; Berglund, L.A.; Oksman, K.; Bismarck, A. On the use of nanocellulose as reinforcement in polymer matrix Composites. Compos. Sci. Technol. 2014, 105, 15-27. [CrossRef] 
121. de Koster, S.A.L.; Mors, R.M.; Nugteren, H.W.; Jonkers, H.M.; Meesters, G.M.H.; van Ommena, J.R. Geopolymer coating of bacteria-containing granules for use in self-healing concrete. Procedia Eng. 2015, 102, 475-484. [CrossRef]

122. Hisseine, O.A.; Wilson, W.; Sorelli, L.; Tolnai, B.; Tagnit-Hamou, A. Nanocellulose for improved concrete performance: A macro-to-micro investigation for disclosing the effects of cellulose filaments on strength of cement systems. Constr. Build. Mater. 2019, 206, 84-96. [CrossRef] 